\title{
Cutaneous Squamous Cell Carcinoma: From Biology to Therapy
}

\author{
Roberto Corchado-Cobos ${ }^{1,2,+}$, Natalia García-Sancha ${ }^{1,2, \dagger}{ }^{,}$Rogelio González-Sarmiento ${ }^{2,3}$ (D), \\ Jesús Pérez-Losada ${ }^{1,2}$ and Javier Cañueto ${ }^{1,2,4, * \mathbb{D}}$ \\ 1 Instituto de Biología Molecular y Celular del Cáncer (IBMCC)-Centro de Investigación del \\ cáncer (CIC)-CSIC, Laboratory 7, 37007 Salamanca, Spain; rober.corchado@usal.es (R.C.-C.); \\ nataliagarciasancha@usal.es (N.G.-S.); jperezlosada@usal.es (J.P.-L.) \\ 2 Instituto de Investigación Biomédica de Salamanca (IBSAL), Complejo Asistencial Universitario \\ de Salamanca, Hospital Virgen de la Vega, 37007 Salamanca, Spain; gonzalez@usal.es \\ 3 Molecular Medicine Unit, Department of Medicine, University of Salamanca, 37007 Salamanca, Spain \\ 4 Department of Dermatology, Complejo Asistencial Universitario de Salamanca, 37007 Salamanca, Spain \\ * Correspondence: jcanueto@usal.es; Tel.: +34-923-291-100 (ext. 55574) \\ + These authors contributed equally to this work.
}

Received: 2 March 2020; Accepted: 20 April 2020; Published: 22 April 2020

\begin{abstract}
Cutaneous squamous cell carcinoma (CSCC) is the second most frequent cancer in humans and its incidence continues to rise. Although CSCC usually display a benign clinical behavior, it can be both locally invasive and metastatic. The signaling pathways involved in CSCC development have given rise to targetable molecules in recent decades. In addition, the high mutational burden and increased risk of CSCC in patients under immunosuppression were part of the rationale for developing the immunotherapy for CSCC that has changed the therapeutic landscape. This review focuses on the molecular basis of CSCC and the current biology-based approaches of targeted therapies and immune checkpoint inhibitors. Another purpose of this review is to explore the landscape of drugs that may induce or contribute to the development of CSCC. Beginning with the pathogenetic basis of these drug-induced CSCCs, we move on to consider potential therapeutic opportunities for overcoming this adverse effect.
\end{abstract}

Keywords: cutaneous squamous cell carcinoma; immunotherapy; epidermal growth factor receptor (EGFR) inhibitors; BRAF inhibitors; azathioprine; cyclosporine

\section{Introduction}

Cutaneous squamous cell carcinoma (CSCC) is the second most frequent cancer in humans, with an estimated incidence of 1 million cases each year in the US. This figure continues to rise, and is an underestimate [1,2]. The number of CSCCs has increased from $50 \%$ to $300 \%$ in the last three decades [3], and by 2030 its incidence in European countries will be twice the current level [4]. It is estimated that the risk of developing a CSCC at some point in life is $7 \%$ to $11 \%$ in the Caucasian population [5] (from $9 \%$ to $14 \%$ in men and from $4 \%$ to $9 \%$ in women) [6].

While it usually exhibits benign clinical behavior, it can be locally invasive and metastatic. Ten-year survival after surgery exceeds $90 \%$ for CSCC, but drops dramatically when metastases occur [7]. The frequency of lymph node metastases is around $4 \%$, and mortality rates are nearly $2 \%$. Given its high frequency, CSCC has a significant impact on overall mortality [8]. It is the second most common cause of death from skin cancer after melanoma and is responsible for the majority of deaths from skin cancer in people older than 85 years [3]. In some areas of the US, it has a mortality comparable to that of renal, oropharyngeal, and melanoma carcinomas [3]. 
CSCC arises from the malignant proliferation of epidermal keratinocytes. There are environmental and constitutional risk factors for its development. With respect to the former, older age, male sex, fair skin, immunosuppression, and a previous history of actinic keratosis (AK) are of known importance. Chronic sun exposure is the most important and well-known environmental factor associated with CSCC [9-14]. Solid-organ transplant recipients, who have a human papillomavirus infection or chronic lymphocytic leukemia, have a higher risk of developing CSCC than the general population [15-18]. AK is considered a premalignant lesion that may progress to an invasive CSCC, and is the most significant predictive factor of CSCC [19].

Several molecular pathways have been implicated in CSCC development. Ultraviolet-induced P53 mutations are early events in CSCC, and are responsible for great genomic instability $[10,20]$. CSCC has the greatest mutational burden of all solid tumors, which, as we will see later, has therapeutic implications [21]. Other genetic changes occur subsequently in other suppressor genes, such as CDKN2A and NOTCH [22,23], and in oncogenes, such as RAS [24]. The accumulation of mutations ultimately involves various signaling pathways [25], including the activation of the NF-kB, MAPK, and PI3K/AKT/mTOR pathways [26,27], which mediate epidermal growth factor receptor (EGFR) overexpression. Epigenetic changes may also occur [28].

Surgery is the cornerstone of the management of CSCC, and radiotherapy is sometimes also implemented. However, a subset of patients with locally advanced and metastatic CSCC may benefit from systemic treatments [29]. The signaling pathways involved in CSCC development have given rise to targetable molecules in recent decades. Moreover, the high mutational burden and increased risk of CSCC in patients under immunosuppression were part of the rationale for developing the immunotherapy for CSCC that has changed the therapeutic landscape in recent years [30]. This review focuses on the molecular basis of CSCC and the current biology-based approaches of targeted therapies and immune checkpoint inhibitors. Another purpose of this review is to explore the landscape of drugs that may induce CSCC. Beginning with the pathogenetic basis of these drug-induced CSCCs, we move on to consider potential therapeutic opportunities for overcoming this adverse effect.

\section{Molecular Basis of CSCC}

Cutaneous squamous cell cancer is one of the most highly mutated human cancers [21,31]. A deeper knowledge of the molecular basis of CSCC would be useful for developing better ways of treating this disease.

The mutation of the tumor suppressor gene TP53 has an important role early in the pathogenesis of CSCC and occurs in 54\%-95\% of cases [10,20,32]. Mutations of TP53 are induced by ultraviolet radiation (UVR), the most important environmental risk factor for CSCC, and are reported in pre-malignant AK lesions and CSCC [33,34]. UVR-induced mutagenesis results in characteristic C-T and CC-TT dipyrimidine transitions, which enable tumor cells to prevent apoptosis and to promote clonal expansion of p53 mutant keratinocytes [35]. The role of $p 53$ in ultraviolet B-induced carcinogenesis has been confirmed in $p 53^{-/-}$mice, which have an increased propensity for developing AK lesions and CSCCs secondary to ultraviolet B (UVB) exposure [36,37]. Furthermore, several groups have confirmed the presence of $p 53$ mutations in CSCC cell lines [38,39]. P53 mutations are an early event in CSCC development and are ultimately responsible for great genomic instability.

Other mutations subsequently occur in tumor suppressors, such as CDKN2A and NOTCH, and in oncogenes, such as RAS. [22]. The CDKN2A gene encodes two alternatively spliced proteins, p16INK4a and p14ARF. The inactivation of the CDKN2A locus may be due to loss of heterozygosity, point mutations, and promoter hypermethylation [23]. Loss of function of either p16INK4a or p14ARF may lead to unrestrained cell cycling and uncontrolled cell growth mediating pRB [40] and p53 [41]. On the other hand, loss of function NOTCH1 and NOTCH2 mutations are identified in more than $75 \%$ of CSCCs [42]. In vivo mouse studies show that Notch1 deletion, a mutation that occurs early in CSCC, results in the development of skin tumors and facilitation of chemically-induced skin 
carcinogenesis $[43,44]$. The Notch1 gene is a direct target of $p 53$ [45], and keratinocyte-specific ablation of Notch1 disrupts the balance between growth and differentiation [46]. The upregulation of the Wnt/beta-catenin pathway, which may result from Notch1 loss of function, facilitates skin tumor development and promotion [43], and is at least partly dependent on p21WAP/Cip1 [47]. In vivo studies of Notch1-deficient mouse skin showed an increase in fibroplasia, angiogenesis, and inflammation, demonstrating the importance of the stromal microenvironment in CSCC development [48].

Loss of the NOTCH1 gene may have cooperative effects with Ras-activation in keratinocyte transformation [22,45]. Regarding RAS genes, HRAS mutations ( $3 \%-20 \%$ of CSCCs), rather than NRAS and KRAS, are commonly associated with CSCC [21,31]. Ras has been implicated in the initiation of CSCC in a murine chemical carcinogenesis model [49], and mediating CDK4, in the induction of cell cycle arrest and transformation of primary keratinocytes into invasive carcinoma [50]. HRAS mutations were found at a higher frequency in CSCC lesions arising in melanoma patients treated with BRAF-inhibition [51]. RAS activation promotes upregulation of downstream MAPK and $\mathrm{PI} 3 \mathrm{~K} / \mathrm{AKT} / \mathrm{mTOR}$ intracellular signaling. These pathways, in non- $R A S$ mutant CSCCs, may also result from alternative mechanisms, including EGFR overexpression or PTEN inactivation.

EGFR overexpression is common in CSCC, and is associated with the acquisition of a more aggressive phenotype and a poor prognosis [26,52]. EGFR is a member of the ErbB family of tyrosine kinase receptors that transmit a growth-inducing signal to cells that have been stimulated by an EGFR ligand. The union of ligand with EGFR produces a conformational change that allows a homodimerization with another EGFR or heterodimerization with another ErbB family member, both of which induce activation [53]. The pathways affected by the activation of EGFR include RAS-RAF-MEK-MAPK, PLC-gamma/PKC, and PI3K/AKT/mTOR. STAT and NF-kB can also be activated [54]. All these pathways are frequently altered in tumors, including CSCC [55], and trigger increased proliferation, migration, survival, resistance to apoptosis, and altered differentiation. The EGFR and downstream pathways can both be targeted with a variety of drugs to inhibit CSCC progression, as discussed below.

Therefore, epigenetic events play important roles in AK and CSCC [56]. CSCC includes the promoter hypermethylation of previous genes, such as $p 16 I N K 4 a$ and $p 14 A R F$, as well as CDH1, $R B 1, M G M T$, and RASSF1, among others. These genes are involved in cycle regulation, DNA repair, epithelial adhesion, and signal transduction, while hypermethylation of $\mathrm{CpG}$ islands in the promoter regions produces transcriptional silencing [28]. MicroRNAs also have an important role; some act as oncogenes and others as tumor suppressors [57], and some are regulated by epigenetic factors. Recurrent copy number aberration has been noted in the development of CSCC (loss of heterozygosity at $3 p, 8 p, 9 p, 9 q, 13 q$, and $17 q$ and chromosomal gain of $11 q$ and $8 q$ ), including the formation of isochromosomes, chromosomal deletions, and whole-arm translocation [58].

Finally, the tumor microenvironment is important in the carcinogenesis of CSCC [59], attracting greater attention as its relevance in tumor development has become apparent [60,61]. One of the main components of the tumor microenvironment is inflammation [61], which may act as a tumor promoter [62,63]. The lack of inflammatory response is relevant in tumor progression [64]. Recent studies demonstrate that the CSCC tumor microenvironment is enriched in cancer-associated fibroblasts (CAFs) [65] and tumor-associated macrophages [66]. Tumor stromal cells are implicated in the invasion, metastases, tumor progression, and response to chemotherapy $[67,68]$. Cellular and molecular components of the tumor microenvironment are of great importance in the effect of immunotherapy, as described below. 


\section{Treatment of CSCC}

\subsection{Targeted Therapy in CSCC}

\subsubsection{EGFR Inhibitors}

Current strategies in cancer therapy have pointed towards the interruption of signaling pathways that are involved in its pathogenesis. EGFR inhibitors were one of the first systemic therapies tested to treat CSCC. Some studies demonstrated that EGFR could be relevant to CSCC development, and in the context of the low effectiveness of drugs for treating CSCC, this was a logical and promising pathway to explore. EGFR inhibitors were tested in other cancers and yielded reasonable responses [69-72], and some isolated cases showed an anti-EGFR response in CSCC [73-77], prompting the design of clinical trials.

Targeting EGFR inhibits the PI3K/AKT/mTOR and RAS/RAF/ERK signal transduction pathways [78]. There are two classes of EGFR inhibitors: monoclonal antibodies that block the extracellular domain of the receptor (e.g., cetuximab, panitumumab, nimotuzumab, zalutumumab), and small-molecule tyrosine kinase inhibitors (TKIs), which block tyrosine kinase activity and thereby inactivate downstream cellular pathways (e.g., gefitinib, erlotinib, afatinib, lapatinib, neratinib, dacomitinib). Monoclonal antibodies and TKIs have been evaluated in clinical trials for poor-prognosis CSCC but are currently off label.

Cetuximab is a human-mouse chimeric monoclonal antibody that competitively binds to the extracellular domain of EGFR and inhibits dimerization of the receptor and the subsequent downstream signaling. Cetuximab is a U.S. Food and Drug Administration (FDA)-approved drug for colorectal and head and neck cancers and has shown some clinical efficacy as a first-line treatment in patients with unresectable CSCC [79]. Cetuximab was the first EGFR inhibitor to be evaluated in CSCC in a phase II trial. In that study, cetuximab showed valuable clinical activity with an overall disease control rate of $69 \%$ and a response rate (RR) of $28 \%$ at six weeks, including two complete remissions $(6 \%)$ and eight partial remissions $(22 \%)$. To confirm these results, a larger clinical trial (NCT03325738) is currently underway. Cetuximab is also being tested in combination with radiotherapy (NCT01979211), lenvatinib, which is a TKI (NCT03524326), avelumab, which is an anti-PD-L1 checkpoint inhibitor (NCT03944941), pembrolizumab, which is directed against as programmed cell death 1 protein (PD-1) (NCT03082534), and before surgery, as a neoadjuvant therapy (NCT02324608). Cetuximab is well-tolerated, but skin reactions may develop as side-effects in more than $80 \%$ of patients, mainly presenting as an acne-like rash, pruritus, desquamation, hypertrichosis, or nail disorders that must be treated [80-82]. The presence of acne-like eruption in patients under treatment has been associated with better response [79,83]. Another monoclonal antibody, panitumumab, was evaluated in 16 patients with incurable CSCC, five of whom (31\%) showed a response [84]. Panitumumab is a good alternative to cetuximab when anaphylaxis occurs [85].

Small-molecule TKIs, like gefitinib, erlotinib, and lapatinib, have been partially effective in patients with CSCC. Gefitinib demonstrated modest activity in metastatic and locoregional recurrent CSCC with an overall RR of $16 \%$ and a disease control rate of 51\% [86] (NCT00054691). Indeed, as neoadjuvant therapy before standard surgery or radiotherapy, gefitinib achieves a $45.5 \% \mathrm{RR}$ in patients with aggressive or recurrent CSCC [87] (NCT00126555). In a single-arm phase II clinical trial, erlotinib exhibited a RR of $10 \%$ and progression-free survival (PFS) of 4.7 months in patients with recurrent or metastatic CSCC [88] (NCT01198028). Erlotinib has been used to inhibit EGFR in a three-dimensional in vitro human skin model, in which it resulted in a significant reduction of epidermal thickness [89]. Lapatinib, a dual TKI that blocks the HER2/neu and EGFR pathways, has been used to treat patients with CSCC and AK. It produced tumor reduction in two out of eight patients and AK reduction in seven out of eight patients, encouraging larger clinical trials [90]. In vitro studies demonstrate that lapatinib produces cell-cycle arrest, autophagy induction, and epithelial-to-mesenchymal inhibition in the CSCC A431 cell line [91]. 
The efficacy of EGFR inhibitors was somewhat lower than expected, and a better selection of patients should optimize the drug's usefulness. It should be borne in mind that these targeted therapies, which inhibit signaling pathways that contribute to the CSCC progression, frequently disrupt skin homeostasis and produce side effects.

\subsubsection{Other Targeted Therapies in CSCC}

The involvement of RAS/RAF/MEK/ERK and PI3K/AKT/mTOR pathways in cancer has led to the development of several inhibitors that target them [92,93]. In CSCC, a recent in vivo study demonstrated that the inhibition of MEK with trametinib and cobimetinib induces senescence in CSCC cell lines and reduces tumor growth in a mouse model [94]. Moreover, cobimetinib is being studied in combination with atezolizumab, a PD-L1 inhibitor, in metastatic or locally advanced and unresectable CSCCs, and locally advanced CSCCs that are technically resectable but where surgery could produce disfigurement (NCT03108131). mTOR inhibitors such as rapamycin are currently being used to decrease the risk of CSCC development in immunosuppressed patients that receive traditional immunosuppression [95-97]. Combining topical mTOR inhibitors and AKT inhibitors (PHT-427) enhances the chemopreventive effects of rapamycin [98]. Pan-PI3K and selective PI3K inhibitors have been developed to treat other cancers [99]. In CSCC, GDC-0084 and LY3023414, which are novel small-molecule PI3K-mTOR dual inhibitors, inhibit survival and proliferation and promote apoptosis in CSCC cells. Moreover, these drugs inhibit A431 xenograft tumor growth $[100,101]$. Thus, targeting pathways downstream of EGFR could be a practical option for attacking CSCC. All the clinical trials that are currently being conducted with targeted therapies are listed in Table 1.

Table 1. Clinical trials of targeted therapies in cutaneous squamous cell carcinoma (CSCC) (revised until 29 January 2020).

\begin{tabular}{|c|c|c|c|c|}
\hline Drug & Treatment & Conditions & Current State & NCT Code \\
\hline \multirow{7}{*}{ Cetuximab } & Alone & $\begin{array}{c}\text { Locally advanced and } \\
\text { metastatic CSCC surgically } \\
\text { unresectable }\end{array}$ & $\begin{array}{c}\text { Completed ( } 28 \% \text { response rate, } \\
6 \% \text { complete remission, } \\
2 \% \text { partial remission) }\end{array}$ & NCT00240682 \\
\hline & Alone & $\begin{array}{l}\text { Locally advanced and } \\
\text { metastatic CSCC } \\
\text { surgically unresectable }\end{array}$ & Completed & NCT03325738 \\
\hline & $\begin{array}{l}\text { Alone (neoadjuvant } \\
\text { therapy) }\end{array}$ & $\begin{array}{l}\text { Aggressive locally } \\
\text { advanced CSCC }\end{array}$ & Recruiting & NCT02324608 \\
\hline & $\begin{array}{l}\text { Combination with } \\
\text { post-operative radiation }\end{array}$ & $\begin{array}{l}\text { Locally advanced head and } \\
\text { neck CSCC }\end{array}$ & Active, not recruiting & NCT01979211 \\
\hline & $\begin{array}{l}\text { Combination with } \\
\text { pembrolizumab }\end{array}$ & Recurrent/metastatic CSCC & Recruiting & NCT03082534 \\
\hline & $\begin{array}{c}\text { Combination with } \\
\text { lenvatinib }\end{array}$ & Advanced CSCC & Recruiting & NCT03524326 \\
\hline & $\begin{array}{l}\text { Combination with } \\
\text { avelumab }\end{array}$ & Advanced CSCC & Recruiting & NCT03944941 \\
\hline \multirow{2}{*}{ Gefitinib } & $\begin{array}{l}\text { Alone (neoadjuvant } \\
\text { therapy) }\end{array}$ & Locally advanced/recurrent CSCC & Completed ( $45.5 \%$ response rate) & NCT00126555 \\
\hline & Alone & $\begin{array}{c}\text { Metastatic or } \\
\text { locorregional recurrent }\end{array}$ & Completed (16\% response rate) & NCT00054691 \\
\hline \multirow{3}{*}{ Erlotinib } & Alone & Recurrent/metastatic CSCC & Completed (10\% response rate) & NCT01198028 \\
\hline & $\begin{array}{l}\text { Combination with } \\
\text { radiotherapy }\end{array}$ & Advanced head and neck CSCC & Completed & NCT00369512 \\
\hline & Alone (before surgery) & Head and neck CSCC & Active, not recruiting & NCT00954226 \\
\hline Cobimetinib & $\begin{array}{l}\text { Combination with } \\
\text { atezolizumab }\end{array}$ & CSCC & Recruiting & NCT03108131 \\
\hline
\end{tabular}

\subsection{Immunotherapy in CSCC}

Tumor cells produce neoantigens that are recognized and targeted by the immune system. When a T-cell recognizes the antigen expressed by the Human leukocyte antigen (HLA) complex 
in the tumor cell, co-receptors act as activators and inhibitors of the immune response [102]. Inhibitory receptors, such as programmed cell death 1 protein (PD-1) and Cytotoxic T-Lymphocyte Antigen 4 (CTLA4), are known as "immune checkpoint" receptors. PD-1 is an inhibitor co-receptor expressed on the surface of T-cells, B-cells, monocytes, natural killer cells, and dendritic cells [103]. This transmembrane protein binds to two ligands, PD-L1 and PD-L2, which are present on the surface of the tumor cell, and their interaction triggers a signal that inhibits the activated T-cells and induces immunological exhaustion via anergy and T-cell apoptosis $[102,104,105]$. The PD-L1/PD-1 axis is a primary mechanism of cancer immune evasion, and this was the rationale for developing new drugs that have emerged in recent years. Targeting the immune checkpoint proteins with monoclonal antibodies has yielded a clinical benefit in cancer $[106,107]$, and dramatically changed prospects for the treatment of some types of cancer, such as melanoma [108]. An established tumor is composed both by the neoplastic cells and the tumor microenvironment. The latter is composed both by the tumor stroma and the inflammatory infiltrate. The tumor microenvironment, and not only the neoplastic cells, can also be modulated to destroy the neoplastic cells. Indeed, most immune checkpoint inhibitors are directed towards the lymphocytes, which belong to the tumor microenvironment, in order to enhance the immune response [109].

PD-1 inhibitors of several forms of cancer have been released, but given the low responsiveness of CSCC to other systemic treatments, some isolated cases were treated with drugs directed towards this axis and responded well $[110,111]$. These preliminary results justified closer examination of this pathway and its potential therapeutic role in CSCC. Some studies demonstrated the presence of cell surface PD-1/PD-L1 in human tumors, and this expression has been linked to poor clinical outcomes in a variety of cancers [112-116], including CSCC [117,118]. CSCC has the highest mutational burden of all tumors, and is a good candidate for immunotherapy treatment [21]. Tumors with a higher tumor mutational burden are known to be more responsive to immune checkpoint inhibitors [119-121]. In addition, the higher risk of immunocompromised patients developing CSCC indicates the importance of the immune system in this tumor [122,123]. For these reasons, clinical trials with these drugs for the treatment of CSCC were designed.

Cemiplimab is the first drug approved by the FDA and the European Medicines Agency (EMA) for the treatment of locally advanced and metastatic CSCC [124]. It is a human monoclonal antibody directed against PD-1, and has demonstrated efficacy in immunocompetent patients with advanced CSCC and with metastatic disease, yielding RRs of 50\% and $47 \%$, respectively [124]. Cemiplimab is currently being tested in patients with recurrent stage III-IV head and neck CSCC before surgery as neoadjuvant therapy (NCT03565783), and in patients with recurrent CSCC as a pre-operative intralesional injection (NCT03889912). Future trials will focus on cemiplimab as an adjuvant drug versus placebo after surgery and radiotherapy in patients with high-risk CSCC (NCT03969004), as monotherapy, or in combination with RP1 oncolytic virus in patients with locally advanced or metastatic CSCC (NCT04050436).

Other immunotherapeutic drugs are under evaluation in CSCC. Pembrolizumab is a human PD-1-blocking antibody indicated for the treatment of non-small-cell lung, head and neck, gastric, cervical, hepatocellular, and endometrial cancers, melanoma, Hodgkin's lymphoma, and Merkel cell, urothelial, renal cell, small-cell lung, and esophageal carcinomas [125]. In CSCC, pembrolizumab is being tested in a phase II study of 150 adults with recurrent/metastatic or locally advanced unresectable CSCC (MK-3475-629/KEYNOTE-629, NCT03284424). The interim results of the preview clinical trial (CARSKIN, NCT02883556) presented at the American Society of Clinical Oncology (ASCO) meeting 2018 showed high RRs (42\%) and a durable response, with a median of around seven months in patients with unresectable CSCC [126]. Pembrolizumab is also being examined in participants with locally advanced CSCC versus placebo after surgery and radiation (MK-3475-630/KEYNOTE-630, NCT03833167). It is being investigated as an addition to postoperative radiotherapy in resected cutaneous squamous cell cancer of the head and neck (NCT03057613) to assess safety with dose-limiting responses. Finally, 
pembrolizumab is being tested in combination with cetuximab (NCT03082534), AST-008 (NCT03684785), abexinostat (NCT035890054), and sonidegib (NCT04007744) in different stages of CSCC.

Nivolumab, another PD-1 inhibitor, is being studied in patients with CSCC in monotherapy (NCT04204837, NCT03834233) or combination with pembrolizumab (NCT02955290), and there have already been case reports demonstrating its clinical efficacy and good tolerability [127]. Nivolumab is also being tested in combination with ipilimumab, an anti-CTLA-4 monoclonal antibody, in patients who are immunosuppressed due to having received a kidney transplant and who have unresectable or metastatic CSCC (NCT03816332). Pembrolizumab and nivolumab are FDA-approved for treating unresectable or metastatic melanoma but have yet to be approved for the treatment of CSCC. The most frequently reported side-effects of immune checkpoint inhibitors are diarrhea and fatigue, and they are usually low-grade side-effects. Immune checkpoint inhibitors can cause inflammation in any organ/system of the body, and thus it is important to take it seriously if the patient presents colitis, pneumonitis, hepatitis, thyroiditis, or hypophysitis. These autoimmune side-effects may sometimes be severe and force a treatment cycle to be discontinued or even withdrawn. Headache, pruritus, and dermatitis may be expected as well [128].

In addition to the evidence from clinical trials, there are several case reports of the efficacy of immunotherapy in CSCC-immunocompetent patients [129-132]. Transplant patients represent a group in which the use of checkpoint inhibitors presents a problem because enhanced T-cell activation can lead to allograft rejection $[106,133,134]$. Limited data exist because transplant patients are often excluded from clinical trials, and only data from isolated cases are available $[130,135,136]$.

All the clinical trials with immunotherapy that are currently underway are listed in Table 2. Figure 1 shows the therapeutic landscape of CSCC.

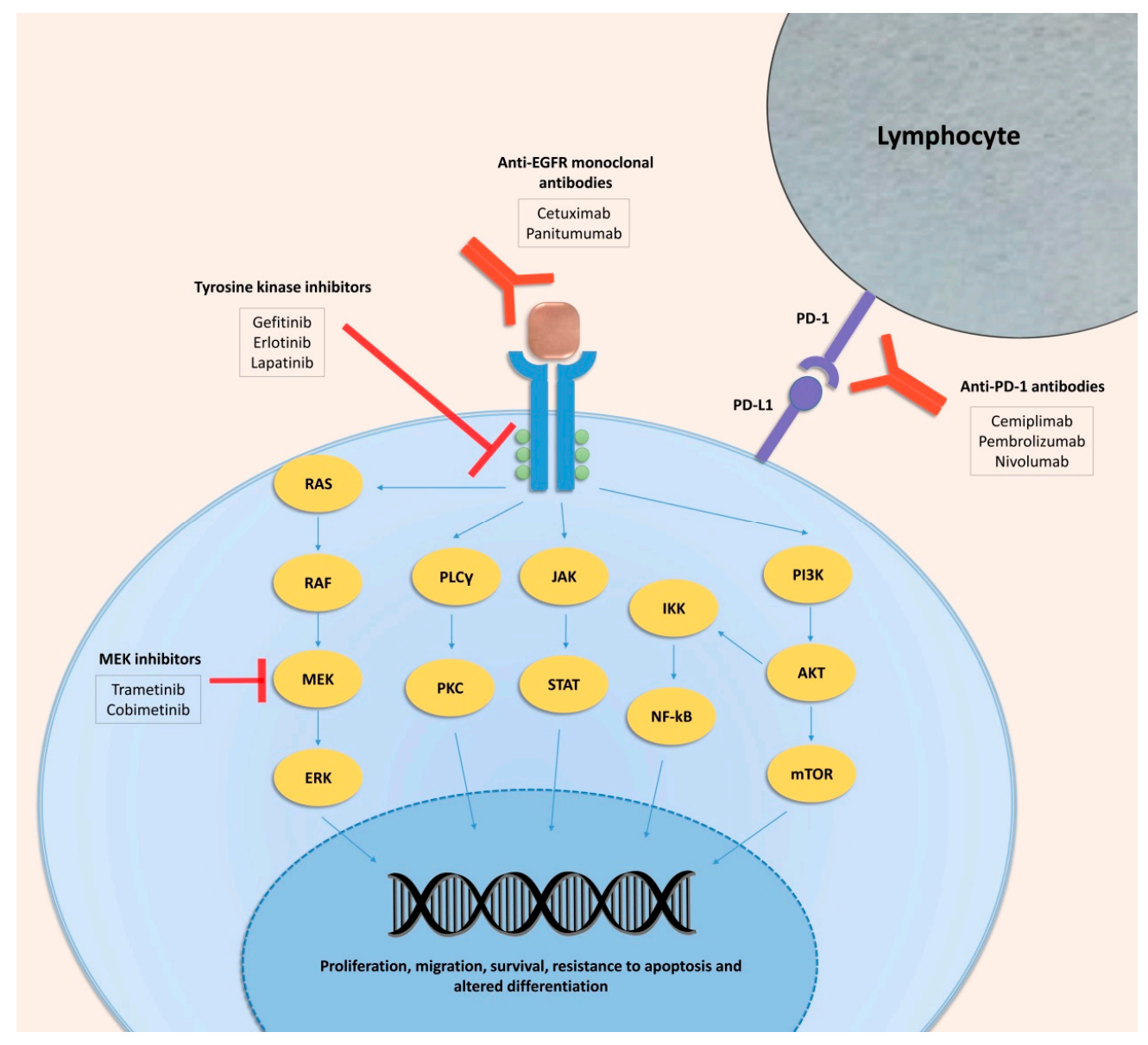

Figure 1. Therapeutic landscape of cutaneous squamous cell carcinoma. 
Table 2. Clinical trials of immunotherapy in cutaneous squamous cell carcinoma (revised until 29 January 2020).

\begin{tabular}{|c|c|c|c|c|}
\hline Drug & Treatment & Conditions & Current State & NCT Code \\
\hline \multirow{4}{*}{ Cemiplimab } & Alone & $\begin{array}{l}\text { Advanced and } \\
\text { metastatic CSCC }\end{array}$ & $\begin{array}{l}\text { Completed }(47 \%-50 \% \text { response } \\
\text { rate) Recruiting next phase }\end{array}$ & $\begin{array}{l}\text { NCT02383212 } \\
\text { NCT02760498 }\end{array}$ \\
\hline & $\begin{array}{l}\text { Alone (pre-operative } \\
\text { therapy intralesional) }\end{array}$ & Recurrent CSCC & Recruiting & NCT03889912 \\
\hline & $\begin{array}{c}\text { Alone or } \\
\text { combination with RP1 }\end{array}$ & $\begin{array}{l}\text { Advanced or } \\
\text { metastatic CSCC }\end{array}$ & Recruiting & NCT04050436 \\
\hline & Alone & $\begin{array}{l}\text { Unresectable locally } \\
\text { recurrent and/or } \\
\text { metastatic CSCC }\end{array}$ & Recruiting & NCT04242173 \\
\hline \multirow{7}{*}{ Pembrolizumab } & Alone & $\begin{array}{l}\text { Locally advanced or } \\
\text { metastatic CSCC }\end{array}$ & $\begin{array}{c}\text { Active, not recruiting (preview } \\
\text { results presented in ASCO } \\
\text { show } 42 \% \\
\text { response rate) }\end{array}$ & NCT02883556 \\
\hline & Alone & $\begin{array}{l}\text { Locally advanced and } \\
\text { metastatic CSCC }\end{array}$ & Active, not recruiting & NCT02964559 \\
\hline & $\begin{array}{l}\text { Adjuvant therapy after } \\
\text { surgery and } \\
\text { radiotherapy }\end{array}$ & $\begin{array}{l}\text { High risk locally } \\
\text { advanced CSCC }\end{array}$ & Recruiting & NCT03833167 \\
\hline & $\begin{array}{l}\text { Combination with } \\
\text { abexinostat }\end{array}$ & $\begin{array}{c}\text { Stage III-IV CSCC } \\
\text { of head } \\
\text { and neck }\end{array}$ & Recruiting & NCT03590054 \\
\hline & $\begin{array}{l}\text { Combination with } \\
\text { sonidegib }\end{array}$ & $\begin{array}{l}\text { Stage IV CSCC of head } \\
\text { and neck }\end{array}$ & Not yet recruiting & NCT04007744 \\
\hline & $\begin{array}{c}\text { Combination with } \\
\text { nivolumab and CIMAvax } \\
\text { vaccine }\end{array}$ & $\begin{array}{l}\text { Stage III-IV CSCC of } \\
\text { head and neck }\end{array}$ & Recruiting & NCT02955290 \\
\hline & $\begin{array}{l}\text { Combination with } \\
\text { SO-C101 }\end{array}$ & $\begin{array}{c}\text { Advanced/metastatic } \\
\text { CSCC }\end{array}$ & Recruiting & NCT04234113 \\
\hline \multirow{4}{*}{ Nivolumab } & Alone & $\begin{array}{c}\text { Locally } \\
\text { advanced/metastatic } \\
\text { CSCC }\end{array}$ & Recruiting & NCT04204837 \\
\hline & Alone & Advanced CSCC & Recruiting & NCT03834233 \\
\hline & $\begin{array}{l}\text { Alone or combination } \\
\text { with ipilimumab }\end{array}$ & $\begin{array}{l}\text { Metastatic CSCC in } \\
\text { immunosuppressed patients }\end{array}$ & Recruiting & NCT03816332 \\
\hline & $\begin{array}{l}\text { Combination with } \\
\text { pembrolizumab and } \\
\text { CIMAvax vaccine }\end{array}$ & $\begin{array}{l}\text { Stage III-IV CSCC of } \\
\text { head and neck }\end{array}$ & Recruiting & NCT02955290 \\
\hline
\end{tabular}

\section{Pharmacologically Induced Cutaneous Squamous Cell Carcinoma}

Several drugs have been developed for CSCC treatment, but the disease may actually be induced by drugs as well. Molecular mechanisms underlie pharmacologically-induced CSCC, and a sound knowledge of them could help physicians better tackle this tumor. Drug-induced CSCC is poorly covered in the literature, and for this reason, we focus on this CSCC in the last part of this review. 


\subsection{Immunosuppressive Drugs and CSCC}

The immunosuppressive therapy used in organ transplant recipients (OTRs) to prevent allograft rejection promotes cutaneous infection and skin neoplasms [15,122]. The classic immunosuppressant drugs used for organ transplantation are glucocorticosteroids (prednisone and prednisolone), calcineurin inhibitors (cyclosporine and tacrolimus), and anti-proliferative agents (azathioprine and mycophenolic acid). Here we focus on cyclosporine and azathioprine.

\subsubsection{Cyclosporine and CSCC}

Cyclosporine is a calcineurin inhibitor that increases the risk of CSCC, especially under UVR [137-139]. Cyclosporine A reduces UVB-induced DNA damage repair and inhibits apoptosis in human keratinocytes by inhibiting the nuclear factor of activated T-cells (NFAT) [140]. Calcineurin inhibition is known to selectively induce the expression of activating transcription factor 3 (ATF3), which downregulated p53 expression and increased CSCC formation in a mouse model and in human CSCCs [141]. In vitro studies demonstrated that chronic treatment of human HaCaT keratinocytes with cyclosporine enhances AKT activation by suppressing PTEN, and promotes tumor growth of the CSCC A431 cell line in immune-deficient nude mice [142,143]. Furthermore, cyclosporine enhances epithelial-to-mesenchymal transition involving the upregulation of TGF $\beta$ signaling [144].

The increased risk of CSCC in patients under cyclosporine has led physicians to search for different options. Some studies of tacrolimus, a calcineurin inhibitor introduced to replace cyclosporine, demonstrated no difference in a comparison of overall cancer rates of the two drugs [145]; however, more recent data from a clinical trial and from in vivo studies indicate a lower skin cancer risk associated with tacrolimus $[146,147]$. Nevertheless, the most important drugs for preventing cyclosporine-induced CSCC development are the mTOR inhibitors.

The newest immunosuppressants used for OTRs are sirolimus (rapamycin) and everolimus. Both inhibit interleukin (IL)-2 and IL-15 via mTOR. It is not known whether these inhibitors have anticarcinogenic effects [148]. Preliminary data suggest that conversion from calcineurin inhibitors to sirolimus reduces the incidence of skin cancer in renal graft recipients [95,97], possibly because sirolimus reduces vascularization and the thickness of post-transplant CSCCs [149]. The change of therapy from calcineurin inhibitors to sirolimus in patients with one CSCC lowered the risk of a new CSCC, and metastasis events only occurred in patients who received calcineurin inhibitors [96], the effect being maintained over five years of follow-up [150]. In vivo studies of hairless mice show that sirolimus significantly increases the latency of large tumors and reduces their multiplicity. Tumors from the rapamycin group have a lower UV-signature p53 mutation rate [151]. Case reports of conversion to everolimus show a reduced likelihood of CSCC development [152].

Recent studies have shown that cyclosporine exposure upregulates IL-22R1 [153] and causes increased JAK1, STAT1, and STAT3 expression. Using ruxolitinib, an FDA-approved JAK1/2 inhibitor, in human CSCC cells and xenografts reduces proliferation and growth. This could be a feasible option for preventing CSCC in OTRs who face long-term immunosuppression [154].

\subsubsection{Azathioprine and CSCC}

In a cohort study of 361 renal transplant recipients, the immunosuppressant drug azathioprine increased the risk of CSCC 2.4-fold [155]; and in an organ transplantation cohort of 207 patients, post-transplant azathioprine treatment increased the risk of CSCC compared with controls in a dose-dependent manner [156]. A systematic review and meta-analysis of 27 studies confirmed the association of OTRs treated with azathioprine and CSCC [157]. It is clear that azathioprine enhances the effect of UVR on skin cancer risk, and indeed, it strongly induces and promotes CSCC in hairless mice exposed to UVR [158]. Azathioprine photosensitizes the skin to UVR by changing the absorption interval of DNA upon incorporation of 6-thioguanine, the active metabolite of azathioprine. UVR absorption then induces the formation of reactive oxygen species that have been linked to DNA 
damage and cutaneous malignancies [159-161]. Whole-exome sequencing has revealed a novel CSCC mutational signature, which is associated with chronic exposure to azathioprine [39].

To reduce the risk of CSCC associated with this drug, azathioprine can be replaced by mycophenolate, leading to lower levels of DNA 6-thioguanine, skin ultraviolet A (UVA) sensitivity, and DNA damage, and a lower risk of CSCC [146,162,163]. However, another study suggests that the calcineurin inhibitor tacrolimus and mycophenolate mofetil (MMF) inhibit UVB-induced DNA damage repair, demonstrating the tumor-promoting action of these immunosuppressants [164].

\subsubsection{Voriconazole and CSCC}

Voriconazole, an antifungal used to prevent and treat invasive fungal infections after lung transplantation, has been associated with an increased risk of developing CSCC [165]. Voriconazole causes photosensitivity [166] in a dose-dependent manner [167]. The mechanism underlying this may arise from a primary metabolite, voriconazole $\mathrm{N}$-oxide, which absorbs UVA and UVB wavelengths [166,168]. Expression arrays of in vitro cultures of primary human keratinocytes exposed to voriconazole also show that this drug inhibits terminal epithelial differentiation pathways, resulting in poor formation of epithelial layers that are important for photoprotection, favoring its phototoxicity [169]. In vitro and in vivo assays demonstrated that voriconazole and its product inhibit catalase, raising intracellular levels of UV-associated oxidative stress and DNA damage in keratinocytes to promote skin carcinogenesis [170]. While photoprotection is fundamental for preventing CSCC, this is especially important in patients under voriconazole.

\subsection{Targeted Therapies}

\subsubsection{Sonic-Hedgehog Inhibitors and CSCC}

Medications to treat other skin cancers, such as melanoma and basal cell carcinoma (BCC), can paradoxically lead to the development of CSCC. Vismodegib is a smoothened inhibitor (Hedgehog pathway inhibitor) that the FDA and EMA have approved for treating locally advanced and metastatic BCC [171]. The association of vismodegib with CSCC was reported in several case reports [172-174], and a retrospective cohort study highlighted this increased risk [175]. Some researchers disputed the latter study [176], and a subsequent paper failed to replicate such an association [177]. Furthermore, squamous metaplasia has been found in BCCs treated with vismodegib [178]. Nevertheless, there is some evidence to suggest that hedgehog inhibitors may indeed increase the risk of CSCC. The mechanism of action of vismodegib to promote CSCC is thought to be the activation of the RAS/MAPK pathway, which is responsible for CSCC progression [179].

A CSCC may arise from a BCC because both develop from the same target cell, as some authors have suggested. Two studies revealed new roles for Ptch1 that lie at the nexus between BCC and CSCC formation $[180,181]$. Ptch1 gene is thought to occupy a critical role in determining the basal or squamous cell lineage [181], and its polymorphisms are involved in cell fate decisions. In BCC, loss of Ptch1 activates the Sonic-Hedgehog pathway, but the overexpression of Ptch1 promotes an alternative cell-fate decision, leading to increased CSCC susceptibility [180].

\subsubsection{BRAF Inhibitors and CSCC}

$B R A F$ is mutated in around $50 \%$ of melanomas, and some years ago, the therapeutic landscape of this tumor broadened through the development of BRAF inhibitors [182], specifically vemurafenib and dabrafenib [183]. These drugs provided greater overall survival and PFS compared with dacarbazine $[184,185]$, but they also increased the risk of CSCC development [186-188]. The effectiveness of these drugs stems from their ability to attenuate the MAPK pathway, which is downstream of constitutive BRAF activation [189]. However, BRAF inhibitors are capable, paradoxically, of activating the MAPK pathway in cells containing non-mutated $B R A F$, and this pathway is essential for CSCC development [51,190-192]. The inhibition of MEK proved to be effective in preventing CSCC 
while on BRAF inhibitors, and thereafter BRAF inhibitors were combined with MEK inhibitors to avoid these side effects. Specifically, vemurafenib is combined with cobimetinib [193], and dabrafenib with trametinib [194]. A meta-analysis of five phase III randomized controlled trials, 17 phase II trials, and two phase IV trials [195] demonstrated that combined BRAF and MEK inhibition (trametinib) reduces the incidence of CSCC relative to BRAF monotherapy, as seen in another study [196]. More recent work demonstrated that BRAF inhibitors induce RAS mutations that are essential for MAPK activation. RAS mutations were detected in $21 \%-60 \%$ of lesions after BRAF inhibitor treatment in contrast to 3\%-30\% in normal CSCCs [51,197]. A mutational signature has been noted in squamous proliferative lesions induced by BRAF inhibitors that differs from the mutation pattern seen in spontaneous CSCCs [198]. Additionally, human papillomaviruses (HPVs) are detected more frequently in BRAF inhibitor-induced CSCCs, which means that HPV might accelerate keratinocyte oncogenesis in this subset of patients [199].

Other than MEK inhibitors, the inhibition of cyclooxygenase (COX)-2 has been evaluated as a strategy to prevent BRAF-inhibitor-mediated CSCC development. Experimental investigations that induce CSCC carcinogenesis by UVR have shown that COX-2 inhibitors (celecoxib and diclofenac) decrease prostaglandin production, thereby mitigating CSCC development [200,201]. Moreover, celecoxib delayed the onset of CSCC in a mouse model mediated by DMBA/TPA and of CSCC induced by the BRAF inhibitor PLX7420, reducing the tumor burden by $90 \%$ [202]. All the drugs that may contribute to the development of CSCC are listed in Table 3.

Table 3. Pharmacologically-induced CSCC.

\begin{tabular}{|c|c|c|c|}
\hline Drug & Treatment & Mechanisms to Promote CSCC & $\begin{array}{l}\text { Options to Reduce } \\
\text { CSCC Risk }\end{array}$ \\
\hline \multirow{4}{*}{ Cyclosporine } & \multirow{4}{*}{ Immunosuppressant } & $\begin{array}{l}\text { Reduces UVB-induced DNA damage repair } \\
\text { and inhibits apoptosis by inhibiting nuclear } \\
\text { factor of activated T-cells (NFAT) [140] }\end{array}$ & \multirow{4}{*}{$\begin{array}{l}\text { Sirolimus and } \\
\text { everolimus } \\
{[95-97,149-152]}\end{array}$} \\
\hline & & $\begin{array}{l}\text { Induces the expression of ATF3, which } \\
\text { downregulates p53 and increases CSCC } \\
\text { formation [141] }\end{array}$ & \\
\hline & & $\begin{array}{c}\text { Enhances AKT activation by suppressing PTEN } \\
\text { and promotes tumor growth }[142,143]\end{array}$ & \\
\hline & & $\begin{array}{c}\text { Enhances epithelial-to-mesenchymal transition } \\
\text { involving the upregulation of TGF } \beta \\
\text { signaling [144] }\end{array}$ & \\
\hline Azathioprine & Immunosuppressant & $\begin{array}{c}\text { Photosensitizes the skin to ultraviolet radiation } \\
\text { (UVR) by changing the absorption interval of } \\
\text { DNA upon incorporation of 6-thioguanine and } \\
\text { induces the formation of reactive oxygen } \\
\text { species [159-161] }\end{array}$ & $\begin{array}{l}\text { Mycophenolate mofetil } \\
{[146,162,163]}\end{array}$ \\
\hline \multirow{3}{*}{ Voriconazole } & \multirow{3}{*}{ Antifungal } & $\begin{array}{l}\text { The primary metabolite, voriconazole N-oxide, } \\
\text { absorbs UVA and UVB wavelengths and causes } \\
\text { photosensitivity [166-168] }\end{array}$ & \multirow[t]{3}{*}{ Photoprotection } \\
\hline & & $\begin{array}{c}\text { Inhibits terminal epithelial differentiation } \\
\text { pathways resulting in poor formation of } \\
\text { epithelial layers that are important for } \\
\text { photoprotection [169] }\end{array}$ & \\
\hline & & $\begin{array}{c}\text { Inhibits catalase, raising intracellular levels of } \\
\text { UV-associated oxidative stress and DNA } \\
\text { damage [170] }\end{array}$ & \\
\hline $\begin{array}{l}\text { Vismodegib } \\
\text { (Sonic-hedgehog } \\
\text { inhibitor) }\end{array}$ & Basal cell carcinoma & Activates RAS-MAPK pathway [179] & Close follow-up \\
\hline $\begin{array}{l}\text { Vemurafenib and } \\
\text { dabrafenib } \\
\text { (BRAF inhibitors) }\end{array}$ & Melanoma & $\begin{array}{l}\text { Activate, paradoxically, MAPK pathway and } \\
\text { induce RAS mutations }[51,190-192,197]\end{array}$ & $\begin{array}{c}\text { BRAF inhibitors + MEK } \\
\text { inhibitors [193-196] or } \\
\text { BRAF inhibitors + } \\
\text { cyclooxygenase } \\
\text { (COX)-2 inhibitors } \\
\text { [200,202] }\end{array}$ \\
\hline
\end{tabular}




\section{Conclusions}

In recent years, a deeper understanding of the molecular bases of cutaneous squamous cell carcinogenesis (CSCC) has helped identify novel therapies. EGFR inhibitors were found to be promising drugs in CSCC, based on several studies that suggested an important role for this pathway in CSCC development at a time when there was little to offer patients by way of effective treatment. Subsequently, other targets were evaluated and continue to be developed. More recently, the high mutational burden of this tumor and the increased risk of CSCC in immunosuppressed patients have raised the possibility of using immunotherapy to treat CSCC. As the new checkpoint inhibitors are surprisingly effective in other tumors, some CSCC cases have also been treated, with anti-PD- 1 yielding particularly good responses. This prompted the design of clinical trials, and cemiplimab was the first inhibitor to be approved for use. It seems likely that other checkpoint inhibitors will be incorporated into the therapeutic arsenal of CSCC in the near future.

It is important to emphasize that patients who are receiving drug treatments that are associated with increased susceptibility to developing CSCC may require dermatological supervision, especially if any suspicious skin lesion arises.

The major message emerging from our review is that we should guard against the view that CSCC is a tumor with a good prognosis simply because it usually has a favorable evolution. In truth, its high incidence means that the absolute frequency of complicated and disseminated cases will also be high.

Metastatic CSCC remains a therapeutic challenge. The new arsenal of drugs that target different signaling pathways, especially immunotherapeutic medications, opens up new possibilities for treating CSCC patients, and we may expect these to be increasingly incorporated into the new wave of personalized and precision medicine protocols.

Funding: Javier Cañueto is partially supported by the grants PI18/000587 (Instituto de Salud Carlos III cofinanciado con fondos FEDER) and GRS 1835/A/18 (Gerencia Regional de Salud de Castilla y León).

Conflicts of Interest: The authors declare no conflicts of interest. The funders had no role in the design of the study; in the collection, analyses, or interpretation of data; in the writing of the manuscript, or in the decision to publish the results.

\section{References}

1. Rogers, H.W.; Weinstock, M.A.; Feldman, S.R.; Coldiron, B.M. Incidence Estimate of Nonmelanoma Skin Cancer (Keratinocyte Carcinomas) in the U.S. Population, 2012. JAMA Dermatol. 2015, 151, 1081-1086. [CrossRef] [PubMed]

2. Muzic, J.G.; Schmitt, A.R.; Wright, A.C.; Alniemi, D.T.; Zubair, A.S.; Olazagasti Lourido, J.M.; Sosa Seda, I.M.; Weaver, A.L.; Baum, C.L. Incidence and Trends of Basal Cell Carcinoma and Cutaneous Squamous Cell Carcinoma: A Population-Based Study in Olmsted County, Minnesota, 2000 to 2010. Mayo Clin. Proc. 2017, 92, 890-898. [CrossRef] [PubMed]

3. Brougham, N.D.; Tan, S.T. The incidence and risk factors of metastasis for cutaneous squamous cell carcinoma-Implications on the T-classification system. J. Surg. Oncol. 2014, 110, 876-882. [CrossRef]

4. Leiter, U.; Keim, U.; Eigentler, T.; Katalinic, A.; Holleczek, B.; Martus, P.; Garbe, C. Incidence, Mortality, and Trends of Nonmelanoma Skin Cancer in Germany. J. Investig. Dermatol. 2017, 137, 1860-1867. [CrossRef] [PubMed]

5. Miller, D.L.; Weinstock, M.A. Nonmelanoma skin cancer in the United States: Incidence. J. Am. Acad. Dermatol. 1994, 30, 774-778. [CrossRef]

6. Alam, M.; Ratner, D. Cutaneous squamous-cell carcinoma. N. Engl. J. Med. 2001, 344, 975-983. [CrossRef]

7. Varra, V.; Woody, N.M.; Reddy, C.; Joshi, N.P.; Geiger, J.; Adelstein, D.J.; Burkey, B.B.; Scharpf, J.; Prendes, B.; Lamarre, E.D.; et al. Suboptimal Outcomes in Cutaneous Squamous Cell Cancer of the Head and Neck with Nodal Metastases. Anticancer Res. 2018, 38, 5825-5830. [CrossRef]

8. Schmults, C.D.; Karia, P.S.; Carter, J.B.; Han, J.; Qureshi, A.A. Factors predictive of recurrence and death from cutaneous squamous cell carcinoma: A 10-year, single-institution cohort study. JAMA Dermatol. 2013, 149, 541-547. [CrossRef] 
9. Que, S.K.T.; Zwald, F.O.; Schmults, C.D. Cutaneous squamous cell carcinoma: Incidence, risk factors, diagnosis, and staging. J. Am. Acad. Dermatol. 2018, 78, 237-247. [CrossRef]

10. Brash, D.E.; Rudolph, J.A.; Simon, J.A.; Lin, A.; McKenna, G.J.; Baden, H.P.; Halperin, A.J.; Ponten, J. A role for sunlight in skin cancer: UV-induced p53 mutations in squamous cell carcinoma. Proc. Natl. Acad. Sci. USA 1991, 88, 10124-10128. [CrossRef]

11. Garcovich, S.; Colloca, G.; Sollena, P.; Andrea, B.; Balducci, L.; Cho, W.C.; Bernabei, R.; Peris, K. Skin Cancer Epidemics in the Elderly as An Emerging Issue in Geriatric Oncology. Aging Dis. 2017, 8, 643-661. [CrossRef] [PubMed]

12. Thomas-Ahner, J.M.; Wulff, B.C.; Tober, K.L.; Kusewitt, D.F.; Riggenbach, J.A.; Oberyszyn, T.M. Gender differences in UVB-induced skin carcinogenesis, inflammation, and DNA damage. Cancer Res. 2007, 67, 3468-3474. [CrossRef]

13. Oberyszyn, T.M. Non-melanoma skin cancer: Importance of gender, immunosuppressive status and vitamin D. Cancer Lett. 2008, 261, 127-136. [CrossRef] [PubMed]

14. Gloster, H.M., Jr.; Neal, K. Skin cancer in skin of color. J. Am. Acad. Dermatol. 2006, 55, 741-760, quiz 761-744. [CrossRef]

15. Berg, D.; Otley, C.C. Skin cancer in organ transplant recipients: Epidemiology, pathogenesis, and management. J. Am. Acad. Dermatol. 2002, 47,1-17. [CrossRef]

16. Lindelof, B.; Sigurgeirsson, B.; Gabel, H.; Stern, R.S. Incidence of skin cancer in 5356 patients following organ transplantation. Br. J. Dermatol. 2000, 143, 513-519.

17. Mehrany, K.; Weenig, R.H.; Pittelkow, M.R.; Roenigk, R.K.; Otley, C.C. High recurrence rates of squamous cell carcinoma after Mohs' surgery in patients with chronic lymphocytic leukemia. Dermatol. Surg. 2005, 31, 38-42. [CrossRef]

18. Dang, C.; Koehler, A.; Forschner, T.; Sehr, P.; Michael, K.; Pawlita, M.; Stockfleth, E.; Nindl, I. E6/E7 expression of human papillomavirus types in cutaneous squamous cell dysplasia and carcinoma in immunosuppressed organ transplant recipients. Br. J. Dermatol. 2006, 155, 129-136. [CrossRef]

19. Werner, R.N.; Sammain, A.; Erdmann, R.; Hartmann, V.; Stockfleth, E.; Nast, A. The natural history of actinic keratosis: A systematic review. Br. J. Dermatol. 2013, 169, 502-518. [CrossRef]

20. Ziegler, A.; Jonason, A.S.; Leffell, D.J.; Simon, J.A.; Sharma, H.W.; Kimmelman, J.; Remington, L.; Jacks, T.; Brash, D.E. Sunburn and p53 in the onset of skin cancer. Nature 1994, 372, 773-776. [CrossRef]

21. Pickering, C.R.; Zhou, J.H.; Lee, J.J.; Drummond, J.A.; Peng, S.A.; Saade, R.E.; Tsai, K.Y.; Curry, J.L.; Tetzlaff, M.T.; Lai, S.Y.; et al. Mutational landscape of aggressive cutaneous squamous cell carcinoma. Clin. Cancer Res. 2014, 20, 6582-6592. [CrossRef]

22. South, A.P.; Purdie, K.J.; Watt, S.A.; Haldenby, S.; den Breems, N.; Dimon, M.; Arron, S.T.; Kluk, M.J.; Aster, J.C.; McHugh, A.; et al. NOTCH1 mutations occur early during cutaneous squamous cell carcinogenesis. J. Investig. Dermatol. 2014, 134, 2630-2638. [CrossRef] [PubMed]

23. Brown, V.L.; Harwood, C.A.; Crook, T.; Cronin, J.G.; Kelsell, D.P.; Proby, C.M. p16INK4a and p14ARF tumor suppressor genes are commonly inactivated in cutaneous squamous cell carcinoma. J. Investig. Dermatol. 2004, 122, 1284-1292. [CrossRef] [PubMed]

24. Pierceall, W.E.; Goldberg, L.H.; Tainsky, M.A.; Mukhopadhyay, T.; Ananthaswamy, H.N. Ras gene mutation and amplification in human nonmelanoma skin cancers. Mol. Carcinog. 1991, 4, 196-202. [CrossRef]

25. Ratushny, V.; Gober, M.D.; Hick, R.; Ridky, T.W.; Seykora, J.T. From keratinocyte to cancer: The pathogenesis and modeling of cutaneous squamous cell carcinoma. J. Clin. Investig. 2012, 122, 464-472. [CrossRef]

26. Canueto, J.; Cardenoso, E.; Garcia, J.L.; Santos-Briz, A.; Castellanos-Martin, A.; Fernandez-Lopez, E.; Blanco Gomez, A.; Perez-Losada, J.; Roman-Curto, C. Epidermal growth factor receptor expression is associated with poor outcome in cutaneous squamous cell carcinoma. Br. J. Dermatol. 2017, 176, 1279-1287. [CrossRef]

27. Toll, A.; Salgado, R.; Yebenes, M.; Martin-Ezquerra, G.; Gilaberte, M.; Baro, T.; Sole, F.; Alameda, F.; Espinet, B.; Pujol, R.M. Epidermal growth factor receptor gene numerical aberrations are frequent events in actinic keratoses and invasive cutaneous squamous cell carcinomas. Exp. Dermatol. 2010, 19, 151-153. [CrossRef]

28. Murao, K.; Kubo, Y.; Ohtani, N.; Hara, E.; Arase, S. Epigenetic abnormalities in cutaneous squamous cell carcinomas: Frequent inactivation of the RB1/p16 and p53 pathways. Br. J. Dermatol. 2006, 155, 999-1005. [CrossRef] 
29. Work, G.; Invited, R.; Kim, J.Y.S.; Kozlow, J.H.; Mittal, B.; Moyer, J.; Olenecki, T.; Rodgers, P. Guidelines of care for the management of cutaneous squamous cell carcinoma. J. Am. Acad. Dermatol. 2018, 78, 560-578. [CrossRef]

30. Bottomley, M.J.; Thomson, J.; Harwood, C.; Leigh, I. The Role of the Immune System in Cutaneous Squamous Cell Carcinoma. Int. J. Mol. Sci. 2019, 20, 2009. [CrossRef]

31. Li, Y.Y.; Hanna, G.J.; Laga, A.C.; Haddad, R.I.; Lorch, J.H.; Hammerman, P.S. Genomic analysis of metastatic cutaneous squamous cell carcinoma. Clin. Cancer Res. 2015, 21, 1447-1456. [CrossRef] [PubMed]

32. Brash, D.E.; Ziegler, A.; Jonason, A.S.; Simon, J.A.; Kunala, S.; Leffell, D.J. Sunlight and sunburn in human skin cancer: P53, apoptosis, and tumor promotion. J. Investig. Dermatol. Symp. Proc. 1996, 1, 136-142.

33. Kubo, Y.; Urano, Y.; Yoshimoto, K.; Iwahana, H.; Fukuhara, K.; Arase, S.; Itakura, M. p53 gene mutations in human skin cancers and precancerous lesions: Comparison with immunohistochemical analysis. J. Investig. Dermatol. 1994, 102, 440-444. [CrossRef] [PubMed]

34. Nelson, M.A.; Einspahr, J.G.; Alberts, D.S.; Balfour, C.A.; Wymer, J.A.; Welch, K.L.; Salasche, S.J.; Bangert, J.L.; Grogan, T.M.; Bozzo, P.O. Analysis of the p53 gene in human precancerous actinic keratosis lesions and squamous cell cancers. Cancer Lett. 1994, 85, 23-29. [CrossRef]

35. Wikonkal, N.M.; Brash, D.E. Ultraviolet radiation induced signature mutations in photocarcinogenesis. J. Investig. Dermatol. Symp. Proc. 1999, 4, 6-10. [CrossRef]

36. Berg, R.J.; van Kranen, H.J.; Rebel, H.G.; de Vries, A.; van Vloten, W.A.; Van Kreijl, C.F.; van der Leun, J.C.; de Gruijl, F.R. Early p53 alterations in mouse skin carcinogenesis by UVB radiation: Immunohistochemical detection of mutant p53 protein in clusters of preneoplastic epidermal cells. Proc. Natl. Acad. Sci. USA 1996, 93, 274-278. [CrossRef] [PubMed]

37. Li, G.; Tron, V.; Ho, V. Induction of squamous cell carcinoma in p53-deficient mice after ultraviolet irradiation. J. Investig. Dermatol. 1998, 110, 72-75. [CrossRef] [PubMed]

38. Hassan, S.; Purdie, K.J.; Wang, J.; Harwood, C.A.; Proby, C.M.; Pourreyron, C.; Mladkova, N.; Nagano, A.; Dhayade, S.; Athineos, D.; et al. A Unique Panel of Patient-Derived Cutaneous Squamous Cell Carcinoma Cell Lines Provides a Preclinical Pathway for Therapeutic Testing. Int. J. Mol. Sci. 2019, 20, 3428. [CrossRef]

39. Inman, G.J.; Wang, J.; Nagano, A.; Alexandrov, L.B.; Purdie, K.J.; Taylor, R.G.; Sherwood, V.; Thomson, J.; Hogan, S.; Spender, L.C.; et al. The genomic landscape of cutaneous SCC reveals drivers and a novel azathioprine associated mutational signature. Nat. Commun. 2018, 9, 3667. [CrossRef]

40. Serrano, M.; Hannon, G.J.; Beach, D. A new regulatory motif in cell-cycle control causing specific inhibition of cyclin D/CDK4. Nature 1993, 366, 704-707. [CrossRef]

41. Stott, F.J.; Bates, S.; James, M.C.; McConnell, B.B.; Starborg, M.; Brookes, S.; Palmero, I.; Ryan, K.; Hara, E.; Vousden, K.H.; et al. The alternative product from the human CDKN2A locus, p14(ARF), participates in a regulatory feedback loop with p53 and MDM2. EMBO J. 1998, 17, 5001-5014. [CrossRef] [PubMed]

42. Wang, N.J.; Sanborn, Z.; Arnett, K.L.; Bayston, L.J.; Liao, W.; Proby, C.M.; Leigh, I.M.; Collisson, E.A.; Gordon, P.B.; Jakkula, L.; et al. Loss-of-function mutations in Notch receptors in cutaneous and lung squamous cell carcinoma. Proc. Natl. Acad. Sci. USA 2011, 108, 17761-17766. [CrossRef] [PubMed]

43. Nicolas, M.; Wolfer, A.; Raj, K.; Kummer, J.A.; Mill, P.; van Noort, M.; Hui, C.C.; Clevers, H.; Dotto, G.P.; Radtke, F. Notch1 functions as a tumor suppressor in mouse skin. Nat. Genet. 2003, 33, 416-421. [CrossRef] [PubMed]

44. Proweller, A.; Tu, L.; Lepore, J.J.; Cheng, L.; Lu, M.M.; Seykora, J.; Millar, S.E.; Pear, W.S.; Parmacek, M.S. Impaired notch signaling promotes de novo squamous cell carcinoma formation. Cancer Res. 2006, 66, 7438-7444. [CrossRef] [PubMed]

45. Lefort, K.; Mandinova, A.; Ostano, P.; Kolev, V.; Calpini, V.; Kolfschoten, I.; Devgan, V.; Lieb, J.; Raffoul, W.; Hohl, D.; et al. Notch1 is a p53 target gene involved in human keratinocyte tumor suppression through negative regulation of ROCK1/2 and MRCKalpha kinases. Genes Dev. 2007, 21, 562-577. [CrossRef]

46. Lefort, K.; Dotto, G.P. Notch signaling in the integrated control of keratinocyte growth/differentiation and tumor suppression. Semin. Cancer Biol. 2004, 14, 374-386. [CrossRef]

47. Devgan, V.; Mammucari, C.; Millar, S.E.; Brisken, C.; Dotto, G.P. p21WAF1/Cip1 is a negative transcriptional regulator of Wnt4 expression downstream of Notch1 activation. Genes Dev. 2005, 19, 1485-1495. [CrossRef]

48. Demehri, S.; Turkoz, A.; Kopan, R. Epidermal Notch1 loss promotes skin tumorigenesis by impacting the stromal microenvironment. Cancer Cell 2009, 16, 55-66. [CrossRef] 
49. Spalding, J.W.; Momma, J.; Elwell, M.R.; Tennant, R.W. Chemically induced skin carcinogenesis in a transgenic mouse line (TG.AC) carrying a v-Ha-ras gene. Carcinogenesis 1993, 14, 1335-1341. [CrossRef]

50. Lazarov, M.; Kubo, Y.; Cai, T.; Dajee, M.; Tarutani, M.; Lin, Q.; Fang, M.; Tao, S.; Green, C.L.; Khavari, P.A. CDK4 coexpression with Ras generates malignant human epidermal tumorigenesis. Nat. Med. 2002, 8, 1105-1114. [CrossRef]

51. Su, F.; Viros, A.; Milagre, C.; Trunzer, K.; Bollag, G.; Spleiss, O.; Reis-Filho, J.S.; Kong, X.; Koya, R.C.; Flaherty, K.T.; et al. RAS mutations in cutaneous squamous-cell carcinomas in patients treated with BRAF inhibitors. N. Engl. J. Med. 2012, 366, 207-215. [CrossRef]

52. Shimizu, T.; Izumi, H.; Oga, A.; Furumoto, H.; Murakami, T.; Ofuji, R.; Muto, M.; Sasaki, K. Epidermal growth factor receptor overexpression and genetic aberrations in metastatic squamous-cell carcinoma of the skin. Dermatology 2001, 202, 203-206. [CrossRef]

53. Wieduwilt, M.J.; Moasser, M.M. The epidermal growth factor receptor family: Biology driving targeted therapeutics. Cell Mol. Life Sci. 2008, 65, 1566-1584. [CrossRef] [PubMed]

54. Oda, K.; Matsuoka, Y.; Funahashi, A.; Kitano, H. A comprehensive pathway map of epidermal growth factor receptor signaling. Mol. Syst. Biol. 2005, 1, 10. [CrossRef] [PubMed]

55. Jost, M.; Kari, C.; Rodeck, U. The EGF receptor-an essential regulator of multiple epidermal functions. Eur. J. Dermatol. 2000, 10, 505-510. [PubMed]

56. Rodriguez-Paredes, M.; Bormann, F.; Raddatz, G.; Gutekunst, J.; Lucena-Porcel, C.; Kohler, F.; Wurzer, E.; Schmidt, K.; Gallinat, S.; Wenck, H.; et al. Methylation profiling identifies two subclasses of squamous cell carcinoma related to distinct cells of origin. Nat. Commun. 2018, 9, 577. [CrossRef]

57. Garcia-Sancha, N.; Corchado-Cobos, R.; Perez-Losada, J.; Canueto, J. MicroRNA Dysregulation in Cutaneous Squamous Cell Carcinoma. Int. J. Mol. Sci. 2019, 20, 2181. [CrossRef]

58. Ashton, K.J.; Carless, M.A.; Griffiths, L.R. Cytogenetic alterations in nonmelanoma skin cancer: A review. Genes Chromosomes Cancer 2005, 43, 239-248. [CrossRef]

59. Dotto, G.P.; Weinberg, R.A.; Ariza, A. Malignant transformation of mouse primary keratinocytes by Harvey sarcoma virus and its modulation by surrounding normal cells. Proc. Natl. Acad. Sci. USA 1988, 85, 6389-6393. [CrossRef]

60. Hanahan, D.; Coussens, L.M. Accessories to the crime: Functions of cells recruited to the tumor microenvironment. Cancer Cell 2012, 21, 309-322. [CrossRef]

61. Junttila, M.R.; de Sauvage, F.J. Influence of tumour micro-environment heterogeneity on therapeutic response. Nature 2013, 501, 346-354. [CrossRef] [PubMed]

62. Grivennikov, S.I.; Greten, F.R.; Karin, M. Immunity, inflammation, and cancer. Cell 2010, 140, 883-899. [CrossRef] [PubMed]

63. Wong, C.E.; Yu, J.S.; Quigley, D.A.; To, M.D.; Jen, K.Y.; Huang, P.Y.; Del Rosario, R.; Balmain, A. Inflammation and Hras signaling control epithelial-mesenchymal transition during skin tumor progression. Genes Dev. 2013, 27, 670-682. [CrossRef] [PubMed]

64. Thommen, D.S.; Schumacher, T.N. T Cell Dysfunction in Cancer. Cancer Cell 2018, 33, 547-562. [CrossRef] [PubMed]

65. Sasaki, K.; Sugai, T.; Ishida, K.; Osakabe, M.; Amano, H.; Kimura, H.; Sakuraba, M.; Kashiwa, K.; Kobayashi, S. Analysis of cancer-associated fibroblasts and the epithelial-mesenchymal transition in cutaneous basal cell carcinoma, squamous cell carcinoma, and malignant melanoma. Hum. Pathol. 2018, 79, 1-8. [CrossRef] [PubMed]

66. Moussai, D.; Mitsui, H.; Pettersen, J.S.; Pierson, K.C.; Shah, K.R.; Suarez-Farinas, M.; Cardinale, I.R.; Bluth, M.J.; Krueger, J.G.; Carucci, J.A. The human cutaneous squamous cell carcinoma microenvironment is characterized by increased lymphatic density and enhanced expression of macrophage-derived VEGF-C. J. Investig. Dermatol. 2011, 131, 229-236. [CrossRef]

67. Chan, J.S.K.; Sng, M.K.; Teo, Z.Q.; Chong, H.C.; Twang, J.S.; Tan, N.S. Targeting nuclear receptors in cancer-associated fibroblasts as concurrent therapy to inhibit development of chemoresistant tumors. Oncogene 2018, 37, 160-173. [CrossRef]

68. Bernat-Peguera, A.; Simon-Extremera, P.; da Silva-Diz, V.; Lopez de Munain, M.; Diaz-Gil, L.; Penin, R.M.; Gonzalez-Suarez, E.; Perez Sidelnikova, D.; Bermejo, O.; Vinals, J.M.; et al. PDGFR-induced autocrine SDF-1 signaling in cancer cells promotes metastasis in advanced skin carcinoma. Oncogene 2019, 38, 5021-5037. [CrossRef] 
69. Shepherd, F.A.; Rodrigues Pereira, J.; Ciuleanu, T.; Tan, E.H.; Hirsh, V.; Thongprasert, S.; Campos, D.; Maoleekoonpiroj, S.; Smylie, M.; Martins, R.; et al. Erlotinib in previously treated non-small-cell lung cancer. N. Engl. J. Med. 2005, 353, 123-132. [CrossRef]

70. Jonker, D.J.; O'Callaghan, C.J.; Karapetis, C.S.; Zalcberg, J.R.; Tu, D.; Au, H.J.; Berry, S.R.; Krahn, M.; Price, T.; Simes, R.J.; et al. Cetuximab for the treatment of colorectal cancer. N. Engl. J. Med. 2007, 357, 2040-2048. [CrossRef]

71. Fukuoka, M.; Yano, S.; Giaccone, G.; Tamura, T.; Nakagawa, K.; Douillard, J.Y.; Nishiwaki, Y.; Vansteenkiste, J.; Kudoh, S.; Rischin, D.; et al. Multi-institutional randomized phase II trial of gefitinib for previously treated patients with advanced non-small-cell lung cancer (The IDEAL 1 Trial) [corrected]. J. Clin. Oncol. 2003, 21, 2237-2246. [CrossRef] [PubMed]

72. Lenz, H.J.; Van Cutsem, E.; Khambata-Ford, S.; Mayer, R.J.; Gold, P.; Stella, P.; Mirtsching, B.; Cohn, A.L.; Pippas, A.W.; Azarnia, N.; et al. Multicenter phase II and translational study of cetuximab in metastatic colorectal carcinoma refractory to irinotecan, oxaliplatin, and fluoropyrimidines. J. Clin. Oncol. 2006, 24, 4914-4921. [CrossRef] [PubMed]

73. Arnold, A.W.; Bruckner-Tuderman, L.; Zuger, C.; Itin, P.H. Cetuximab therapy of metastasizing cutaneous squamous cell carcinoma in a patient with severe recessive dystrophic epidermolysis bullosa. Dermatology 2009, 219, 80-83. [CrossRef] [PubMed]

74. Bauman, J.E.; Eaton, K.D.; Martins, R.G. Treatment of recurrent squamous cell carcinoma of the skin with cetuximab. Arch. Dermatol. 2007, 143, 889-892. [CrossRef]

75. Giacchero, D.; Barriere, J.; Benezery, K.; Guillot, B.; Dutriaux, C.; Mortier, L.; Lacour, J.P.; Thyss, A.; Peyrade, F. Efficacy of cetuximab for unresectable or advanced cutaneous squamous cell carcinoma-A report of eight cases. Clin. Oncol. (R. Coll. Radiol.) 2011, 23, 716-718. [CrossRef]

76. Jalili, A.; Pinc, A.; Pieczkowski, F.; Karlhofer, F.M.; Stingl, G.; Wagner, S.N. Combination of an EGFR blocker and a COX-2 inhibitor for the treatment of advanced cutaneous squamous cell carcinoma. J. Dtsch. Dermatol. Ges. 2008, 6, 1066-1069. [CrossRef]

77. Suen, J.K.; Bressler, L.; Shord, S.S.; Warso, M.; Villano, J.L. Cutaneous squamous cell carcinoma responding serially to single-agent cetuximab. Anticancer Drugs 2007, 18, 827-829. [CrossRef]

78. Wheeler, D.L.; Dunn, E.F.; Harari, P.M. Understanding resistance to EGFR inhibitors-impact on future treatment strategies. Nat. Rev. Clin. Oncol. 2010, 7, 493-507. [CrossRef]

79. Maubec, E.; Petrow, P.; Scheer-Senyarich, I.; Duvillard, P.; Lacroix, L.; Gelly, J.; Certain, A.; Duval, X.; Crickx, B.; Buffard, V.; et al. Phase II study of cetuximab as first-line single-drug therapy in patients with unresectable squamous cell carcinoma of the skin. J. Clin. Oncol. 2011, 29, 3419-3426. [CrossRef]

80. Hu, J.C.; Sadeghi, P.; Pinter-Brown, L.C.; Yashar, S.; Chiu, M.W. Cutaneous side effects of epidermal growth factor receptor inhibitors: Clinical presentation, pathogenesis, and management. J. Am. Acad. Dermatol. 2007, 56, 317-326. [CrossRef]

81. Ocvirk, J.; Cencelj, S. Management of cutaneous side-effects of cetuximab therapy in patients with metastatic colorectal cancer. J. Eur. Acad. Dermatol. Venereol. 2010, 24, 453-459. [CrossRef] [PubMed]

82. Segaert, S.; Van Cutsem, E. Clinical signs, pathophysiology and management of skin toxicity during therapy with epidermal growth factor receptor inhibitors. Ann. Oncol. 2005, 16, 1425-1433. [CrossRef] [PubMed]

83. Bar-Ad, V.; Zhang, Q.E.; Harari, P.M.; Axelrod, R.; Rosenthal, D.I.; Trotti, A.; Jones, C.U.; Garden, A.S.; Song, G.; Foote, R.L.; et al. Correlation Between the Severity of Cetuximab-Induced Skin Rash and Clinical Outcome for Head and Neck Cancer Patients: The RTOG Experience. Int. J. Radiat. Oncol. Biol. Phys. 2016, 95, 1346-1354. [CrossRef] [PubMed]

84. Foote, M.C.; McGrath, M.; Guminski, A.; Hughes, B.G.; Meakin, J.; Thomson, D.; Zarate, D.; Simpson, F.; Porceddu, S.V. Phase II study of single-agent panitumumab in patients with incurable cutaneous squamous cell carcinoma. Ann. Oncol. 2014, 25, 2047-2052. [CrossRef]

85. Marti, A.; Fauconneau, A.; Ouhabrache, N.; Beylot-Barry, M.; Pham-Ledard, A. Complete Remission of Squamous Cell Carcinoma After Treatment With Panitumumab in a Patient With Cetuximab-Induced Anaphylaxis. JAMA Dermatol. 2016, 152, 343-345. [CrossRef]

86. William, W.N., Jr.; Feng, L.; Ferrarotto, R.; Ginsberg, L.; Kies, M.; Lippman, S.; Glisson, B.; Kim, E.S. Gefitinib for patients with incurable cutaneous squamous cell carcinoma: A single-arm phase II clinical trial. J. Am. Acad. Dermatol. 2017, 77, 1110-1113.e2. [CrossRef] 
87. Lewis, C.M.; Glisson, B.S.; Feng, L.; Wan, F.; Tang, X.; Wistuba, I.I.; El-Naggar, A.K.; Rosenthal, D.I.; Chambers, M.S.; Lustig, R.A.; et al. A phase II study of gefitinib for aggressive cutaneous squamous cell carcinoma of the head and neck. Clin. Cancer Res. 2012, 18, 1435-1446. [CrossRef]

88. Gold, K.A.; Kies, M.S.; William, W.N., Jr.; Johnson, F.M.; Lee, J.J.; Glisson, B.S. Erlotinib in the treatment of recurrent or metastatic cutaneous squamous cell carcinoma: A single-arm phase 2 clinical trial. Cancer 2018, 124, 2169-2173. [CrossRef] [PubMed]

89. Commandeur, S.; van Drongelen, V.; de Gruijl, F.R.; El Ghalbzouri, A. Epidermal growth factor receptor activation and inhibition in $3 \mathrm{D}$ in vitro models of normal skin and human cutaneous squamous cell carcinoma. Cancer Sci. 2012, 103, 2120-2126. [CrossRef]

90. Jenni, D.; Karpova, M.B.; Muhleisen, B.; Mangana, J.; Dreier, J.; Hafner, J.; Dummer, R. A prospective clinical trial to assess lapatinib effects on cutaneous squamous cell carcinoma and actinic keratosis. ESMO Open 2016, 1, e000003. [CrossRef] [PubMed]

91. Yao, M.; Shang, Y.Y.; Zhou, Z.W.; Yang, Y.X.; Wu, Y.S.; Guan, L.F.; Wang, X.Y.; Zhou, S.F.; Wei, X. The research on lapatinib in autophagy, cell cycle arrest and epithelial to mesenchymal transition via Wnt/ErK/PI3K-AKT signaling pathway in human cutaneous squamous cell carcinoma. J. Cancer 2017, 8, 220-226. [CrossRef] [PubMed]

92. Yang, J.; Nie, J.; Ma, X.; Wei, Y.; Peng, Y.; Wei, X. Targeting PI3K in cancer: Mechanisms and advances in clinical trials. Mol. Cancer 2019, 18, 26. [CrossRef] [PubMed]

93. Degirmenci, U.; Wang, M.; Hu, J. Targeting Aberrant RAS/RAF/MEK/ERK Signaling for Cancer Therapy. Cells 2020, 9, 198. [CrossRef] [PubMed]

94. Adelmann, C.H.; Truong, K.A.; Liang, R.J.; Bansal, V.; Gandee, L.; Saporito, R.C.; Lee, W.; Du, L.; Nicholas, C.; Napoli, M.; et al. MEK Is a Therapeutic and Chemopreventative Target in Squamous Cell Carcinoma. J. Investig. Dermatol. 2016, 136, 1920-1924. [CrossRef]

95. Campbell, S.B.; Walker, R.; Tai, S.S.; Jiang, Q.; Russ, G.R. Randomized controlled trial of sirolimus for renal transplant recipients at high risk for nonmelanoma skin cancer. Am. J. Transplant. 2012, 12, 1146-1156. [CrossRef]

96. Euvrard, S.; Morelon, E.; Rostaing, L.; Goffin, E.; Brocard, A.; Tromme, I.; Broeders, N.; del Marmol, V.; Chatelet, V.; Dompmartin, A.; et al. Sirolimus and secondary skin-cancer prevention in kidney transplantation. N. Engl. J. Med. 2012, 367, 329-339. [CrossRef]

97. Tessmer, C.S.; Magalhaes, L.V.; Keitel, E.; Valar, C.; Gnatta, D.; Pra, R.L.; Silveira, F.R.; Dos Santos, A.F.; Goldani, J.C.; Garcia, V.D.; et al. Conversion to sirolimus in renal transplant recipients with skin cancer. Transplantation 2006, 82, 1792-1793. [CrossRef]

98. Dickinson, S.E.; Janda, J.; Criswell, J.; Blohm-Mangone, K.; Olson, E.R.; Liu, Z.; Barber, C.; Petricoin, E.F., 3rd; Calvert, V.S.; Einspahr, J.; et al. Inhibition of Akt Enhances the Chemopreventive Effects of Topical Rapamycin in Mouse Skin. Cancer Prev. Res. (Phila.) 2016, 9, 215-224. [CrossRef]

99. Jokinen, E.; Koivunen, J.P. MEK and PI3K inhibition in solid tumors: Rationale and evidence to date. Ther. Adv. Med. Oncol. 2015, 7, 170-180. [CrossRef]

100. Ding, L.T.; Zhao, P.; Yang, M.L.; Lv, G.Z.; Zhao, T.L. GDC-0084 inhibits cutaneous squamous cell carcinoma cell growth. Biochem. Biophys. Res. Commun. 2018, 503, 1941-1948. [CrossRef]

101. Zou, Y.; Ge, M.; Wang, X. Targeting PI3K-AKT-mTOR by LY3023414 inhibits human skin squamous cell carcinoma cell growth in vitro and in vivo. Biochem. Biophys. Res. Commun. 2017, 490, 385-392. [CrossRef] [PubMed]

102. Flies, D.B.; Sandler, B.J.; Sznol, M.; Chen, L. Blockade of the B7-H1/PD-1 pathway for cancer immunotherapy. Yale J. Biol. Med. 2011, 84, 409-421. [PubMed]

103. Keir, M.E.; Butte, M.J.; Freeman, G.J.; Sharpe, A.H. PD-1 and its ligands in tolerance and immunity. Annu. Rev. Immunol. 2008, 26, 677-704. [CrossRef] [PubMed]

104. Barber, D.L.; Wherry, E.J.; Masopust, D.; Zhu, B.; Allison, J.P.; Sharpe, A.H.; Freeman, G.J.; Ahmed, R. Restoring function in exhausted CD8 T cells during chronic viral infection. Nature 2006, 439, 682-687. [CrossRef]

105. Chikuma, S.; Terawaki, S.; Hayashi, T.; Nabeshima, R.; Yoshida, T.; Shibayama, S.; Okazaki, T.; Honjo, T. PD-1-mediated suppression of IL-2 production induces CD8+ T cell anergy in vivo. J. Immunol. 2009, 182, 6682-6689. [CrossRef] 
106. Fisher, J.; Zeitouni, N.; Fan, W.; Samie, F.H. Immune checkpoint inhibitor therapy in solid organ transplant recipients: A patient-centered systematic review. J. Am. Acad. Dermatol. 2019. [CrossRef]

107. Jia, L.; Zhang, Q.; Zhang, R. PD-1/PD-L1 pathway blockade works as an effective and practical therapy for cancer immunotherapy. Cancer Biol. Med. 2018, 15, 116-123. [CrossRef]

108. Nixon, N.A.; Blais, N.; Ernst, S.; Kollmannsberger, C.; Bebb, G.; Butler, M.; Smylie, M.; Verma, S. Current landscape of immunotherapy in the treatment of solid tumours, with future opportunities and challenges. Curr. Oncol. 2018, 25, e373-e384. [CrossRef]

109. Tang, H.; Qiao, J.; Fu, Y.X. Immunotherapy and tumor microenvironment. Cancer Lett. 2016, 370, 85-90. [CrossRef]

110. Falchook, G.S.; Leidner, R.; Stankevich, E.; Piening, B.; Bifulco, C.; Lowy, I.; Fury, M.G. Responses of metastatic basal cell and cutaneous squamous cell carcinomas to anti-PD1 monoclonal antibody REGN2810. J. Immunother. Cancer 2016, 4, 70. [CrossRef]

111. Slater, N.A.; Googe, P.B. PD-L1 expression in cutaneous squamous cell carcinoma correlates with risk of metastasis. J. Cutan. Pathol. 2016, 43, 663-670. [CrossRef]

112. Wang, Y.; Kim, T.H.; Fouladdel, S.; Zhang, Z.; Soni, P.; Qin, A.; Zhao, L.; Azizi, E.; Lawrence, T.S.; Ramnath, N.; et al. PD-L1 Expression in Circulating Tumor Cells Increases during Radio(chemo)therapy and Indicates Poor Prognosis in Non-small Cell Lung Cancer. Sci. Rep. 2019, 9, 566. [CrossRef] [PubMed]

113. Yuan, C.; Liu, Z.; Yu, Q.; Wang, X.; Bian, M.; Yu, Z.; Yu, J. Expression of PD-1/PD-L1 in primary breast tumours and metastatic axillary lymph nodes and its correlation with clinicopathological parameters. Sci. Rep. 2019, 9, 14356. [CrossRef] [PubMed]

114. Gu, X.; Dong, M.; Liu, Z.; Mi, Y.; Yang, J.; Zhang, Z.; Liu, K.; Jiang, L.; Zhang, Y.; Dong, S.; et al. Elevated PD-L1 expression predicts poor survival outcomes in patients with cervical cancer. Cancer Cell Int. 2019, 19, 146. [CrossRef] [PubMed]

115. Takada, K.; Toyokawa, G.; Shoji, F.; Okamoto, T.; Maehara, Y. The Significance of the PD-L1 Expression in Non-Small-Cell Lung Cancer: Trenchant Double Swords as Predictive and Prognostic Markers. Clin. Lung Cancer 2018, 19, 120-129. [CrossRef]

116. Hamanishi, J.; Mandai, M.; Iwasaki, M.; Okazaki, T.; Tanaka, Y.; Yamaguchi, K.; Higuchi, T.; Yagi, H.; Takakura, K.; Minato, N.; et al. Programmed cell death 1 ligand 1 and tumor-infiltrating CD8+ T lymphocytes are prognostic factors of human ovarian cancer. Proc. Natl. Acad. Sci. USA 2007, 104, 3360-3365. [CrossRef]

117. Garcia-Pedrero, J.M.; Martinez-Camblor, P.; Diaz-Coto, S.; Munguia-Calzada, P.; Vallina-Alvarez, A.; Vazquez-Lopez, F.; Rodrigo, J.P.; Santos-Juanes, J. Tumor programmed cell death ligand 1 expression correlates with nodal metastasis in patients with cutaneous squamous cell carcinoma of the head and neck. J. Am. Acad. Dermatol. 2017, 77, 527-533. [CrossRef]

118. Garcia-Diez, I.; Hernandez-Ruiz, E.; Andrades, E.; Gimeno, J.; Ferrandiz-Pulido, C.; Yebenes, M.; Garcia-Patos, V.; Pujol, R.M.; Hernandez-Munoz, I.; Toll, A. PD-L1 Expression is Increased in Metastasizing Squamous Cell Carcinomas and Their Metastases. Am. J. Dermatopathol. 2018, 40, 647-654. [CrossRef]

119. Chan, T.A.; Yarchoan, M.; Jaffee, E.; Swanton, C.; Quezada, S.A.; Stenzinger, A.; Peters, S. Development of tumor mutation burden as an immunotherapy biomarker: Utility for the oncology clinic. Ann. Oncol. 2019, 30, 44-56. [CrossRef]

120. Wu, Y.; Xu, J.; Du, C.; Wu, Y.; Xia, D.; Lv, W.; Hu, J. The Predictive Value of Tumor Mutation Burden on Efficacy of Immune Checkpoint Inhibitors in Cancers: A Systematic Review and Meta-Analysis. Front. Oncol. 2019, 9, 1161. [CrossRef]

121. Voutsadakis, I.A. High Tumor Mutation Burden and Other Immunotherapy Response Predictors in Breast Cancers: Associations and Therapeutic Opportunities. Target. Oncol. 2019. [CrossRef]

122. Mittal, A.; Colegio, O.R. Skin Cancers in Organ Transplant Recipients. Am. J. Transplant. 2017, 17, $2509-2530$. [CrossRef] [PubMed]

123. Bauer, C.; Abdul Pari, A.A.; Umansky, V.; Utikal, J.; Boukamp, P.; Augustin, H.G.; Goerdt, S.; Geraud, C.; Felcht, M. T-lymphocyte profiles differ between keratoacanthomas and invasive squamous cell carcinomas of the human skin. Cancer Immunol. Immunother. 2018, 67, 1147-1157. [CrossRef] [PubMed]

124. Migden, M.R.; Rischin, D.; Schmults, C.D.; Guminski, A.; Hauschild, A.; Lewis, K.D.; Chung, C.H.; Hernandez-Aya, L.; Lim, A.M.; Chang, A.L.S.; et al. PD-1 Blockade with Cemiplimab in Advanced Cutaneous Squamous-Cell Carcinoma. N. Engl. J. Med. 2018, 379, 341-351. [CrossRef] [PubMed]

125. Flynn, J.P.; Gerriets, V. Pembrolizumab. In StatPearls; StatPearls Publishing: Treasure Island, FL, USA, 2019. 
126. Maubec, E.; Boubaya, M.; Petrow, P.; Basset-Seguin, N.; Grob, J.-J.; Dreno, B.; Scheer-Senyarich, I.; Helfen, S.; De Quatrebarbes, J.; Poirier, E.; et al. Pembrolizumab as first line therapy in patients with unresectable squamous cell carcinoma of the skin: Interim results of the phase 2 CARSKIN trial. J. Clin. Oncol. 2018, 36. [CrossRef]

127. Blum, V.; Muller, B.; Hofer, S.; Pardo, E.; Zeidler, K.; Diebold, J.; Strobel, K.; Brand, C.; Aebi, S.; Gautschi, O. Nivolumab for recurrent cutaneous squamous cell carcinoma: Three cases. Eur. J. Dermatol. 2018, 28, 78-81. [CrossRef]

128. Petersen, E.T.; Ahmed, S.R.; Chen, L.; Silapunt, S.; Migden, M.R. Review of systemic agents in the treatment of advanced cutaneous squamous cell carcinoma. Future Oncol. 2019, 15, 3171-3184. [CrossRef]

129. Vaidya, P.; Mehta, A.; Ragab, O.; Lin, S.; In, G.K. Concurrent radiation therapy with programmed cell death protein 1 inhibition leads to a complete response in advanced cutaneous squamous cell carcinoma. JAAD Case Rep. 2019, 5, 763-766. [CrossRef]

130. Chang, A.L.; Kim, J.; Luciano, R.; Sullivan-Chang, L.; Colevas, A.D. A Case Report of Unresectable Cutaneous Squamous Cell Carcinoma Responsive to Pembrolizumab, a Programmed Cell Death Protein 1 Inhibitor. JAMA Dermatol. 2016, 152, 106-108. [CrossRef]

131. Degache, E.; Crochet, J.; Simon, N.; Tardieu, M.; Trabelsi, S.; Moncourier, M.; Templier, I.; Foroni, L.; Lemoigne, A.; Pinel, N.; et al. Major response to pembrolizumab in two patients with locally advanced cutaneous squamous cell carcinoma. J. Eur. Acad. Dermatol. Venereol. 2018, 32, e257-e258. [CrossRef]

132. Vanhakendover, L.; Lebas, E.; Libon, F.; Wauters, O.; Dezfoulian, B.; Marchal, N.; Rorive, A.; Piret, P.; Quatresooz, P.; Jacquemin, D.; et al. Locally advanced and metastatic cutaneous squamous cell carcinoma treated with cemiplimab. Rev. Med. Liege 2019, 74, 436-440. [PubMed]

133. Lipson, E.J.; Bagnasco, S.M.; Moore, J., Jr.; Jang, S.; Patel, M.J.; Zachary, A.A.; Pardoll, D.M.; Taube, J.M.; Drake, C.G. Tumor Regression and Allograft Rejection after Administration of Anti-PD-1. N. Engl. J. Med. 2016, 374, 896-898. [CrossRef] [PubMed]

134. Miller, D.M.; Faulkner-Jones, B.E.; Stone, J.R.; Drews, R.E. Complete pathologic response of metastatic cutaneous squamous cell carcinoma and allograft rejection after treatment with combination immune checkpoint blockade. JAAD Case Rep. 2017, 3, 412-415. [CrossRef] [PubMed]

135. Kacew, A.J.; Harris, E.J.; Lorch, J.H.; Haddad, R.I.; Chau, N.G.; Rabinowits, G.; LeBoeuf, N.R.; Schmults, C.D.; Thakuria, M.; MacConaill, L.E.; et al. Chromosome 3q arm gain linked to immunotherapy response in advanced cutaneous squamous cell carcinoma. Eur. J. Cancer 2019, 113, 1-9. [CrossRef]

136. Borradori, L.; Sutton, B.; Shayesteh, P.; Daniels, G.A. Rescue therapy with anti-programmed cell death protein 1 inhibitors of advanced cutaneous squamous cell carcinoma and basosquamous carcinoma: Preliminary experience in five cases. Br. J. Dermatol. 2016, 175, 1382-1386. [CrossRef]

137. Price, M.L.; Tidman, M.J.; Ogg, C.S.; MacDonald, D.M. Skin cancer and cyclosporine therapy. N. Engl. J. Med. 1985, 313, 1420. [CrossRef]

138. Mortimer, P.S.; Thompson, J.F.; Dawber, R.P.; Ryan, T.J.; Morris, P.J. Hypertrichosis and multiple cutaneous squamous cell carcinomas in association with cyclosporin A therapy. J. R. Soc. Med. 1983, 76, 786-787.

139. Jensen, P.; Moller, B.; Hansen, S. Skin cancer in kidney and heart transplant recipients and different long-term immunosuppressive therapy regimens. J. Am. Acad. Dermatol. 2000, 42, 307. [CrossRef]

140. Yarosh, D.B.; Pena, A.V.; Nay, S.L.; Canning, M.T.; Brown, D.A. Calcineurin inhibitors decrease DNA repair and apoptosis in human keratinocytes following ultraviolet B irradiation. J. Investig. Dermatol. 2005, 125, 1020-1025. [CrossRef]

141. Wu, X.; Nguyen, B.C.; Dziunycz, P.; Chang, S.; Brooks, Y.; Lefort, K.; Hofbauer, G.F.; Dotto, G.P. Opposing roles for calcineurin and ATF3 in squamous skin cancer. Nature 2010, 465, 368-372. [CrossRef]

142. Han, W.; Ming, M.; He, T.C.; He, Y.Y. Immunosuppressive cyclosporin A activates AKT in keratinocytes through PTEN suppression: Implications in skin carcinogenesis. J. Biol. Chem. 2010, 285, 11369-11377. [CrossRef] [PubMed]

143. Han, W.; Soltani, K.; Ming, M.; He, Y.Y. Deregulation of XPC and CypA by cyclosporin A: An immunosuppression-independent mechanism of skin carcinogenesis. Cancer Prev. Res. (Phila.) 2012, 5, 1155-1162. [CrossRef] [PubMed] 
144. Walsh, S.B.; Xu, J.; Xu, H.; Kurundkar, A.R.; Maheshwari, A.; Grizzle, W.E.; Timares, L.; Huang, C.C.; Kopelovich, L.; Elmets, C.A.; et al. Cyclosporine a mediates pathogenesis of aggressive cutaneous squamous cell carcinoma by augmenting epithelial-mesenchymal transition: Role of TGFbeta signaling pathway. Mol. Carcinog 2011, 50, 516-527. [CrossRef] [PubMed]

145. Webster, A.C.; Woodroffe, R.C.; Taylor, R.S.; Chapman, J.R.; Craig, J.C. Tacrolimus versus ciclosporin as primary immunosuppression for kidney transplant recipients: Meta-analysis and meta-regression of randomised trial data. BMJ 2005, 331, 810. [CrossRef] [PubMed]

146. Coghill, A.E.; Johnson, L.G.; Berg, D.; Resler, A.J.; Leca, N.; Madeleine, M.M. Immunosuppressive Medications and Squamous Cell Skin Carcinoma: Nested Case-Control Study Within the Skin Cancer after Organ Transplant (SCOT) Cohort. Am. J. Transplant. 2016, 16, 565-573. [CrossRef]

147. Kauffman, H.M.; Cherikh, W.S.; McBride, M.A.; Cheng, Y.; Hanto, D.W. Post-transplant de novo malignancies in renal transplant recipients: The past and present. Transpl. Int. 2006, 19, 607-620. [CrossRef]

148. Faivre, S.; Kroemer, G.; Raymond, E. Current development of mTOR inhibitors as anticancer agents. Nat. Rev. Drug Discov. 2006, 5, 671-688. [CrossRef]

149. Rival-Tringali, A.L.; Euvrard, S.; Decullier, E.; Claudy, A.; Faure, M.; Kanitakis, J. Conversion from calcineurin inhibitors to sirolimus reduces vascularization and thickness of post-transplant cutaneous squamous cell carcinomas. Anticancer Res. 2009, 29, 1927-1932.

150. Dantal, J.; Morelon, E.; Rostaing, L.; Goffin, E.; Brocard, A.; Tromme, I.; Broeders, N.; Del Marmol, V.; Chatelet, V.; Dompmartin, A.; et al. Sirolimus for Secondary Prevention of Skin Cancer in Kidney Transplant Recipients: 5-Year Results. J. Clin. Oncol. 2018, 36, 2612-2620. [CrossRef]

151. De Gruijl, F.R.; Koehl, G.E.; Voskamp, P.; Strik, A.; Rebel, H.G.; Gaumann, A.; de Fijter, J.W.; Tensen, C.P.; Bavinck, J.N.; Geissler, E.K. Early and late effects of the immunosuppressants rapamycin and mycophenolate mofetil on UV carcinogenesis. Int. J. Cancer 2010, 127, 796-804. [CrossRef]

152. Holdaas, H.; De Simone, P.; Zuckermann, A. Everolimus and Malignancy after Solid Organ Transplantation: A Clinical Update. J. Transplant. 2016, 2016, 4369574. [CrossRef]

153. Abikhair, M.; Mitsui, H.; Yanofsky, V.; Roudiani, N.; Ovits, C.; Bryan, T.; Oberyszyn, T.M.; Tober, K.L.; Gonzalez, J.; Krueger, J.G.; et al. Cyclosporine A immunosuppression drives catastrophic squamous cell carcinoma through IL-22. JCI Insight 2016, 1, e86434. [CrossRef] [PubMed]

154. Abikhair Burgo, M.; Roudiani, N.; Chen, J.; Santana, A.L.; Doudican, N.; Proby, C.; Felsen, D.; Carucci, J.A. Ruxolitinib inhibits cyclosporine-induced proliferation of cutaneous squamous cell carcinoma. JCI Insight 2018, 3. [CrossRef] [PubMed]

155. Ramsay, H.M.; Fryer, A.A.; Hawley, C.M.; Smith, A.G.; Nicol, D.L.; Harden, P.N. Factors associated with nonmelanoma skin cancer following renal transplantation in Queensland, Australia. J. Am. Acad. Dermatol. 2003, 49, 397-406. [CrossRef]

156. Ingvar, A.; Smedby, K.E.; Lindelof, B.; Fernberg, P.; Bellocco, R.; Tufveson, G.; Hoglund, P.; Adami, J. Immunosuppressive treatment after solid organ transplantation and risk of post-transplant cutaneous squamous cell carcinoma. Nephrol. Dial. Transplant. 2010, 25, 2764-2771. [CrossRef]

157. Jiyad, Z.; Olsen, C.M.; Burke, M.T.; Isbel, N.M.; Green, A.C. Azathioprine and Risk of Skin Cancer in Organ Transplant Recipients: Systematic Review and Meta-Analysis. Am. J. Transplant. 2016, 16, 3490-3503. [CrossRef]

158. Kelly, G.E.; Meikle, W.; Sheil, A.G. Effects of immunosuppressive therapy on the induction of skin tumors by ultraviolet irradiation in hairless mice. Transplantation 1987, 44, 429-434. [CrossRef]

159. O’Donovan, P.; Perrett, C.M.; Zhang, X.; Montaner, B.; Xu, Y.Z.; Harwood, C.A.; McGregor, J.M.; Walker, S.L.; Hanaoka, F.; Karran, P. Azathioprine and UVA light generate mutagenic oxidative DNA damage. Science 2005, 309, 1871-1874. [CrossRef]

160. Perrett, C.M.; Walker, S.L.; O’Donovan, P.; Warwick, J.; Harwood, C.A.; Karran, P.; McGregor, J.M. Azathioprine treatment photosensitizes human skin to ultraviolet A radiation. Br. J. Dermatol. 2008, 159, 198-204. [CrossRef]

161. Attard, N.R.; Karran, P. UVA photosensitization of thiopurines and skin cancer in organ transplant recipients. Photochem. Photobiol. Sci. 2012, 11, 62-68. [CrossRef]

162. Hofbauer, G.F.; Attard, N.R.; Harwood, C.A.; McGregor, J.M.; Dziunycz, P.; Iotzova-Weiss, G.; Straub, G.; Meyer, R.; Kamenisch, Y.; Berneburg, M.; et al. Reversal of UVA skin photosensitivity and DNA damage in kidney transplant recipients by replacing azathioprine. Am. J. Transplant. 2012, 12, 218-225. [CrossRef] 
163. Vos, M.; Plasmeijer, E.I.; van Bemmel, B.C.; van der Bij, W.; Klaver, N.S.; Erasmus, M.E.; de Bock, G.H.; Verschuuren, E.A.M.; Racz, E. Azathioprine to mycophenolate mofetil transition and risk of squamous cell carcinoma after lung transplantation. J. Heart Lung Transplant. 2018, 37, 853-859. [CrossRef] [PubMed]

164. Ming, M.; Zhao, B.; Qiang, L.; He, Y.Y. Effect of immunosuppressants tacrolimus and mycophenolate mofetil on the keratinocyte UVB response. Photochem. Photobiol. 2015, 91, 242-247. [CrossRef] [PubMed]

165. Feist, A.; Lee, R.; Osborne, S.; Lane, J.; Yung, G. Increased incidence of cutaneous squamous cell carcinoma in lung transplant recipients taking long-term voriconazole. J. Heart Lung Transplant. 2012, 31, 1177-1181. [CrossRef] [PubMed]

166. Cowen, E.W.; Nguyen, J.C.; Miller, D.D.; McShane, D.; Arron, S.T.; Prose, N.S.; Turner, M.L.; Fox, L.P. Chronic phototoxicity and aggressive squamous cell carcinoma of the skin in children and adults during treatment with voriconazole. J. Am. Acad. Dermatol. 2010, 62, 31-37. [CrossRef]

167. Singer, J.P.; Boker, A.; Metchnikoff, C.; Binstock, M.; Boettger, R.; Golden, J.A.; Glidden, D.V.; Arron, S.T. High cumulative dose exposure to voriconazole is associated with cutaneous squamous cell carcinoma in lung transplant recipients. J. Heart Lung Transplant. 2012, 31, 694-699. [CrossRef]

168. Murayama, N.; Imai, N.; Nakane, T.; Shimizu, M.; Yamazaki, H. Roles of CYP3A4 and CYP2C19 in methyl hydroxylated and N-oxidized metabolite formation from voriconazole, a new anti-fungal agent, in human liver microsomes. Biochem. Pharmacol. 2007, 73, 2020-2026. [CrossRef]

169. Mansh, M.; Ing, L.; Dimon, M.; Celli, A.; Mauro, T.M.; Arron, S.T. Voriconazole exposure regulates distinct cell-cycle and terminal differentiation pathways in primary human keratinocytes. Br. J. Dermatol. 2017, 176, 816-820. [CrossRef]

170. Lee, V.; Gober, M.D.; Bashir, H.; O’Day, C.; Blair, I.A.; Mesaros, C.; Weng, L.; Huang, A.; Chen, A.; Tang, R.; et al. Voriconazole enhances UV-induced DNA damage by inhibiting catalase and promoting oxidative stress. Exp. Dermatol. 2019. [CrossRef]

171. Basset-Seguin, N.; Hauschild, A.; Kunstfeld, R.; Grob, J.; Dreno, B.; Mortier, L.; Ascierto, P.A.; Licitra, L.; Dutriaux, C.; Thomas, L.; et al. Vismodegib in patients with advanced basal cell carcinoma: Primary analysis of STEVIE, an international, open-label trial. Eur. J. Cancer 2017, 86, 334-348. [CrossRef]

172. Saintes, C.; Saint-Jean, M.; Brocard, A.; Peuvrel, L.; Renaut, J.J.; Khammari, A.; Quereux, G.; Dreno, B. Development of squamous cell carcinoma into basal cell carcinoma under treatment with Vismodegib. J. Eur. Acad. Dermatol. Venereol. 2015, 29, 1006-1009. [CrossRef]

173. Aasi, S.; Silkiss, R.; Tang, J.Y.; Wysong, A.; Liu, A.; Epstein, E.; Oro, A.E.; Chang, A.L. New onset of keratoacanthomas after vismodegib treatment for locally advanced basal cell carcinomas: A report of 2 cases. JAMA Dermatol. 2013, 149, 242-243. [CrossRef]

174. Iarrobino, A.; Messina, J.L.; Kudchadkar, R.; Sondak, V.K. Emergence of a squamous cell carcinoma phenotype following treatment of metastatic basal cell carcinoma with vismodegib. J. Am. Acad. Dermatol. 2013, 69, e33-e34. [CrossRef]

175. Mohan, S.V.; Chang, J.; Li, S.; Henry, A.S.; Wood, D.J.; Chang, A.L. Increased Risk of Cutaneous Squamous Cell Carcinoma After Vismodegib Therapy for Basal Cell Carcinoma. JAMA Dermatol. 2016, 152, 527-532. [CrossRef]

176. Puig, S.; Sampogna, F.; Tejera-Vaquerizo, A. Study on the Risk of Cutaneous Squamous Cell Carcinoma After Vismodegib Therapy for Basal Cell Carcinoma: Not a Case-Control Study. JAMA Dermatol. 2016, 152, 1172-1173. [CrossRef]

177. Bhutani, T.; Abrouk, M.; Sima, C.S.; Sadetsky, N.; Hou, J.; Caro, I.; Chren, M.M.; Arron, S.T. Risk of cutaneous squamous cell carcinoma after treatment of basal cell carcinoma with vismodegib. J. Am. Acad. Dermatol. 2017, 77, 713-718. [CrossRef] [PubMed]

178. Bancalari, B.; Llombart, B.; Serra-Guillen, C.; Bernia, E.; Requena, C.; Nagore, E.; Traves, V.; Calomarde, L.; Diago, A.; Guillen, C.; et al. Histologic Changes During Treatment With Vismodegib in Locally Advanced Basal Cell Carcinoma: A Series of 19 Cases. Am. J. Dermatopathol. 2019, 41, 711-717. [CrossRef] [PubMed]

179. Zhao, X.; Ponomaryov, T.; Ornell, K.J.; Zhou, P.; Dabral, S.K.; Pak, E.; Li, W.; Atwood, S.X.; Whitson, R.J.; Chang, A.L.; et al. RAS/MAPK Activation Drives Resistance to Smo Inhibition, Metastasis, and Tumor Evolution in Shh Pathway-Dependent Tumors. Cancer Res. 2015, 75, 3623-3635. [CrossRef] [PubMed]

180. Kang, H.C.; Wakabayashi, Y.; Jen, K.Y.; Mao, J.H.; Zoumpourlis, V.; Del Rosario, R.; Balmain, A. Ptch1 overexpression drives skin carcinogenesis and developmental defects in K14Ptch(FVB) mice. J. Investig. Dermatol. 2013, 133, 1311-1320. [CrossRef] [PubMed] 
181. Wakabayashi, Y.; Mao, J.H.; Brown, K.; Girardi, M.; Balmain, A. Promotion of Hras-induced squamous carcinomas by a polymorphic variant of the Patched gene in FVB mice. Nature 2007, 445, 761-765. [CrossRef]

182. Ribas, A.; Flaherty, K.T. BRAF targeted therapy changes the treatment paradigm in melanoma. Nat. Rev. Clin. Oncol. 2011, 8, 426-433. [CrossRef] [PubMed]

183. Heinzerling, L.; Baiter, M.; Kuhnapfel, S.; Schuler, G.; Keikavoussi, P.; Agaimy, A.; Kiesewetter, F.; Hartmann, A.; Schneider-Stock, R. Mutation landscape in melanoma patients clinical implications of heterogeneity of BRAF mutations. Br. J. Cancer 2013, 109, 2833-2841. [CrossRef] [PubMed]

184. Chapman, P.B.; Hauschild, A.; Robert, C.; Haanen, J.B.; Ascierto, P.; Larkin, J.; Dummer, R.; Garbe, C.; Testori, A.; Maio, M.; et al. Improved survival with vemurafenib in melanoma with BRAF V600E mutation. N. Engl. J. Med. 2011, 364, 2507-2516. [CrossRef] [PubMed]

185. Hauschild, A.; Grob, J.J.; Demidov, L.V.; Jouary, T.; Gutzmer, R.; Millward, M.; Rutkowski, P.; Blank, C.U.; Miller, W.H., Jr.; Kaempgen, E.; et al. Dabrafenib in BRAF-mutated metastatic melanoma: A multicentre, open-label, phase 3 randomised controlled trial. Lancet 2012, 380, 358-365. [CrossRef]

186. Anforth, R.; Menzies, A.; Byth, K.; Carlos, G.; Chou, S.; Sharma, R.; Scolyer, R.A.; Kefford, R.; Long, G.V.; Fernandez-Penas, P. Factors influencing the development of cutaneous squamous cell carcinoma in patients on BRAF inhibitor therapy. J. Am. Acad. Dermatol. 2015, 72, 809-815.e1. [CrossRef] [PubMed]

187. Sufficool, K.E.; Hepper, D.M.; Linette, G.P.; Hurst, E.A.; Lu, D.; Lind, A.C.; Cornelius, L.A. Histopathologic characteristics of therapy-associated cutaneous neoplasms with vemurafenib, a selective BRAF kinase inhibitor, used in the treatment of melanoma. J. Cutan. Pathol. 2014, 41, 568-575. [CrossRef]

188. Harvey, N.T.; Millward, M.; Wood, B.A. Squamoproliferative lesions arising in the setting of BRAF inhibition. Am. J. Dermatopathol. 2012, 34, 822-826. [CrossRef] [PubMed]

189. Bollag, G.; Tsai, J.; Zhang, J.; Zhang, C.; Ibrahim, P.; Nolop, K.; Hirth, P. Vemurafenib: The first drug approved for BRAF-mutant cancer. Nat. Rev. Drug Discov. 2012, 11, 873-886. [CrossRef] [PubMed]

190. Gibney, G.T.; Messina, J.L.; Fedorenko, I.V.; Sondak, V.K.; Smalley, K.S. Paradoxical oncogenesis-The long-term effects of BRAF inhibition in melanoma. Nat. Rev. Clin. Oncol. 2013, 10, 390-399. [CrossRef] [PubMed]

191. Hatzivassiliou, G.; Song, K.; Yen, I.; Brandhuber, B.J.; Anderson, D.J.; Alvarado, R.; Ludlam, M.J.; Stokoe, D.; Gloor, S.L.; Vigers, G.; et al. RAF inhibitors prime wild-type RAF to activate the MAPK pathway and enhance growth. Nature 2010, 464, 431-435. [CrossRef]

192. Poulikakos, P.I.; Zhang, C.; Bollag, G.; Shokat, K.M.; Rosen, N. RAF inhibitors transactivate RAF dimers and ERK signalling in cells with wild-type BRAF. Nature 2010, 464, 427-430. [CrossRef] [PubMed]

193. Larkin, J.; Ascierto, P.A.; Dreno, B.; Atkinson, V.; Liszkay, G.; Maio, M.; Mandala, M.; Demidov, L.; Stroyakovskiy, D.; Thomas, L.; et al. Combined vemurafenib and cobimetinib in BRAF-mutated melanoma. N. Engl. J. Med. 2014, 371, 1867-1876. [CrossRef] [PubMed]

194. Flaherty, K.T.; Infante, J.R.; Daud, A.; Gonzalez, R.; Kefford, R.F.; Sosman, J.; Hamid, O.; Schuchter, L.; Cebon, J.; Ibrahim, N.; et al. Combined BRAF and MEK inhibition in melanoma with BRAF V600 mutations. N. Engl. J. Med. 2012, 367, 1694-1703. [CrossRef]

195. Peng, L.; Wang, Y.; Hong, Y.; Ye, X.; Shi, P.; Zhang, J.; Zhao, Q. Incidence and relative risk of cutaneous squamous cell carcinoma with single-agent BRAF inhibitor and dual BRAF/MEK inhibitors in cancer patients: A meta-analysis. Oncotarget 2017, 8, 83280-83291. [CrossRef] [PubMed]

196. Sanlorenzo, M.; Choudhry, A.; Vujic, I.; Posch, C.; Chong, K.; Johnston, K.; Meier, M.; Osella-Abate, S.; Quaglino, P.; Daud, A.; et al. Comparative profile of cutaneous adverse events: BRAF/MEK inhibitor combination therapy versus BRAF monotherapy in melanoma. J. Am. Acad. Dermatol. 2014, 71, 1102-1109. [CrossRef] [PubMed]

197. Oberholzer, P.A.; Kee, D.; Dziunycz, P.; Sucker, A.; Kamsukom, N.; Jones, R.; Roden, C.; Chalk, C.J.; Ardlie, K.; Palescandolo, E.; et al. RAS mutations are associated with the development of cutaneous squamous cell tumors in patients treated with RAF inhibitors. J. Clin. Oncol. 2012, 30, 316-321. [CrossRef] [PubMed]

198. Clynick, B.; Tabone, T.; Fuller, K.; Erber, W.; Meehan, K.; Millward, M.; Wood, B.A.; Harvey, N.T. Mutational Analysis of BRAF Inhibitor-Associated Squamoproliferative Lesions. J. Mol. Diagn. 2015, 17, 644-651. [CrossRef] 
199. Cohen, D.N.; Lawson, S.K.; Shaver, A.C.; Du, L.; Nguyen, H.P.; He, Q.; Johnson, D.B.; Lumbang, W.A.; Moody, B.R.; Prescott, J.L.; et al. Contribution of Beta-HPV Infection and UV Damage to Rapid-Onset Cutaneous Squamous Cell Carcinoma during BRAF-Inhibition Therapy. Clin. Cancer Res. 2015, 21, 2624-2634. [CrossRef]

200. Pentland, A.P.; Schoggins, J.W.; Scott, G.A.; Khan, K.N.; Han, R. Reduction of UV-induced skin tumors in hairless mice by selective COX-2 inhibition. Carcinogenesis 1999, 20, 1939-1944. [CrossRef]

201. Burns, E.M.; Tober, K.L.; Riggenbach, J.A.; Schick, J.S.; Lamping, K.N.; Kusewitt, D.F.; Young, G.S.; Oberyszyn, T.M. Preventative topical diclofenac treatment differentially decreases tumor burden in male and female Skh-1 mice in a model of UVB-induced cutaneous squamous cell carcinoma. Carcinogenesis 2013, 34, 370-377. [CrossRef]

202. Escuin-Ordinas, H.; Atefi, M.; Fu, Y.; Cass, A.; Ng, C.; Huang, R.R.; Yashar, S.; Comin-Anduix, B.; Avramis, E.; Cochran, A.J.; et al. COX-2 inhibition prevents the appearance of cutaneous squamous cell carcinomas accelerated by BRAF inhibitors. Mol. Oncol. 2014, 8, 250-260. [CrossRef] [PubMed]

(C) 2020 by the authors. Licensee MDPI, Basel, Switzerland. This article is an open access article distributed under the terms and conditions of the Creative Commons Attribution (CC BY) license (http://creativecommons.org/licenses/by/4.0/). 